\title{
A milling machine used for groove making in a tubing inter-rib niche
}

\begin{abstract}
The sealing of shaft cast iron tubing within a tubing Inter-rib niche is often needed during overhauls and repairs of a shaft lining. Leakages or scratches and fractures can occur within the area of individual tubing of the shaft lining. The Przedsiębiorstwo Budowy Szybów S.A. developed special method for the sealing in question. Around the sealed area, a closed circumference groove of a depth smaller than the tubing thickness is made in the inner shaft lining. The sealing element is placed in this groove and then tightened with a spatial insert, with a hole for the injection of the sealing medium. A specially designed milling machine is used for groove making in the tubing lining of the mine shaft. The milling machine is composed of: power transmission system, special construction for mounting the milling machine to tubing and advance mechanism. The milling machine is driven by a battery drill-driver, and the whole device is mounted to the tubing with the use of specially designed guides with handles.
\end{abstract}

Key words: tubing milling machine, shaft lining repairs, tubing lining

\section{INTRODUCTION}

Tubing lining is used as the final lining of shafts sunk in complex hydro-geological conditions, and it is composed of a cylinder made of separate rings. Individual rings are composed of separate, equal segments called tubings. Tubings can be built of reinforced concrete, cast iron and steel. Steel tubings, having dimensions depending on the shaft diameter, have the form of a metal pipe [1].

\subsection{Reasons and examples for tubing lining damages}

Leakages, scratches, and fractures can occur within the area in individual tubings of the excavation lining and this damage to the shaft lining must be re- paired. Material faults and hydro-geological conditions occurring in the rock body are the most common reason for the occurrence of such damage.

In the region of the Upper Silesian Coal Basin, tubing lining is used sporadically because of economic aspects. Mining shaft sections with steel tubing lining are more often observed in the KGHM within Legnica-Głogów copper district. The first damage to iron tubing segments were observed in the 1990's in shafts of the LGOM, in the shaft L-II of the Lubin Mine. The damage comprised segments of the tubing lining, in the ring of upper and lower picotage gap, at the depth of $295.8 \mathrm{~m} \mathrm{(} \sim 50 \mathrm{~m}$ over floor of the Tertiary beds). The damage comprised a break to the horizontal flange directly neighbouring the picotage gap [2,3]. Damage to the segments are shown in Figures 1 and 2. 

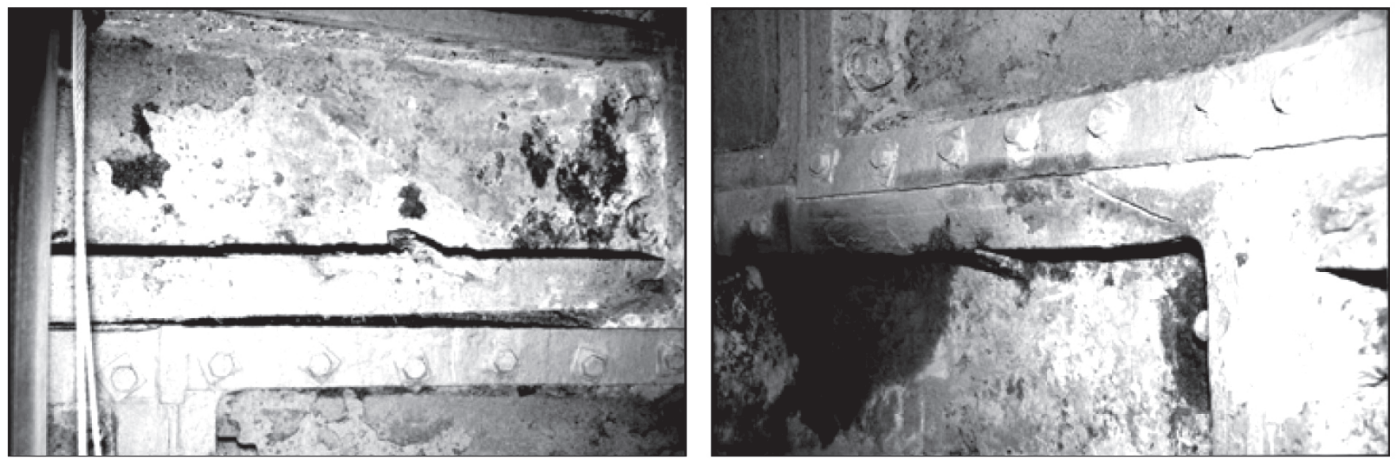

Fig. 1. Damage of the tubing segments of the picotage gap No. 8 in shaft L-II of the Lubin Mine [2]
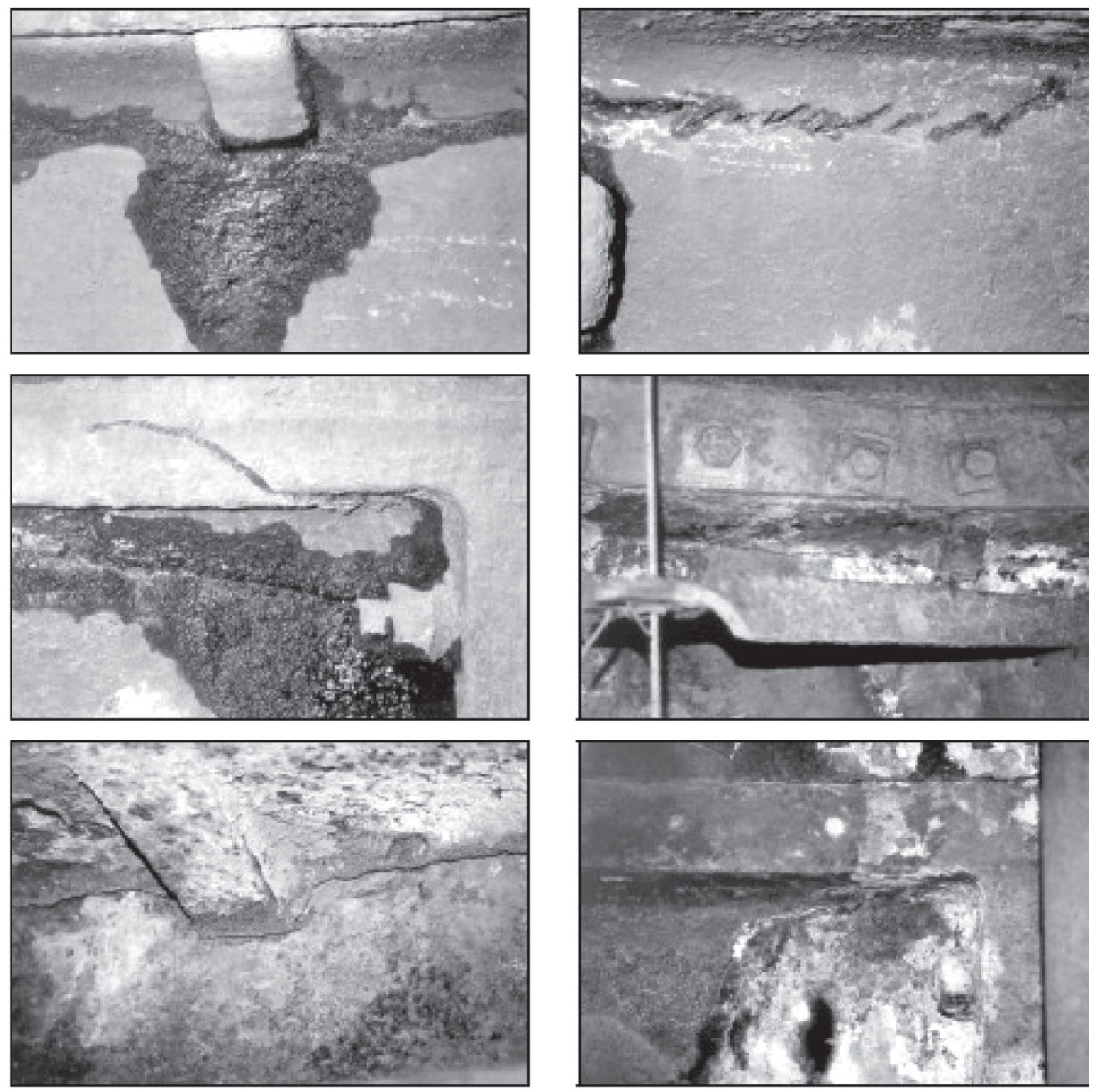

Fig. 2. Damages of tubing segment within area of picotage gaps [2] in the LGOM regions

More or less dangerous damages of the shaft lining were proved during numerous inspections of the shaft lining pipe conducted in the mines of the KGHM. Examples of damage are shown in Figure 2.

On the basis of observation and analyses of the damage, it was proved that the following factors accompany the damage in question:

- occurrence of damage in the majority of tubing rings installed directly on picotage gaps,

- in most cases, the first damage in a given shaft is related to tubing segments within picotage gaps located in the floor of Tertiary beds,
- an increase in the number of damaged tubings within the area of a given ring, with time,

- tendency of the segment damage occurrence on neighbouring picotage gaps,

- lack of tubing segments fractures on picotage gaps within areas with cohesive rocks,

- in almost all cases, the tubing damage was not related to material faults, with the exception of one single case [2].

Problems related to the damage of tubing linings, particularly within tubing inter-rib niche, refer not only to mines and shafts belonging to KGHM. Cases 
of damage to the tubing lining are found in hard coal mines, for example shaft VII of the hard coal mine "Chwałowice" the retention reservoir in the Bogdanka Mine, and the northern shaft of the Ruda Halemba II mine etc. [4-6].

\subsection{Methods of tubing lining protection}

Damage to the shaft tubing lining are directly dangerous for the shaft operation because damage, like fractures for example, are accompanied with more or less intensive water inflow into the shaft. The safety of mining excavations is considered dangerous, because the devastation of the lining usually comprises a bigger zone, and the possibility of more intensive water leakage related with rock mass movements is quite realistic.

\subsubsection{Protection methods}

An analysis of lining damages and deformations of the shaft should be made. Deformation of the rock mass can result in changes to the stress state within the lining and its deformation, and in consequence the destruction of the lining, independent of its material defects.

Therefore, the application of preventive activities which can reduce number and size of lining damage is important. The main preventive activities comprise:

- selection of a suitable exploitation system near the borders of protective pillars;

- preparation of the tubing column should ensure safe operation independent of the exploitation conducted. For that purpose, the following solutions are realised:

- reinforcing of the lining in shafts in the vicinity of picotage gaps via infilling inter-rib niches with reinforced material near the picotage gap,

- making access to tubing columns on the picotage gaps via drilling holes in the wooden gap sealing. According to safety regulations, the length of the boreholes cannot be bigger than the flange thickness [5].

\subsubsection{Methods of tubing lining sealing - Polish patent descriptions}

On the basis of the published patents, three methods of mine shaft tubing lining reinforcement can be distinguished. Polish patent P.361415 describes the method of repairing damaged segments of tubing lining where furnishing cages are installed. Such a prepared tubing inter-rib space is filled with reinforcing material.

Another solution is presented in the description of the patent PL 179822 B1, where a method for repairing mine tubings with an inter-rib niche is described. According to this method, first the sealing medium is injected into the leakage occurrence zone, which should stop the water leakage. When the leakage is stopped, a glue layer is put on the inner tubing surface, and then a metal insert is pressed into the glue layer. The metal insert has an outer shape which is the mirror image of the tubing niche and, independently of the gluing process, the insert is additionally screwed to the tubing ribs and flange. Basically, the arc length of the insert corresponds to the niche arc length between the ribs of the tubing segment, however it is not obligatory. However, the length of the insert is always such that is ensures the requisite water-tightness and structural strength.

\section{A NEW METHOD OF TUBING LINING SEALING}

As mentioned before, the need to seal shaft tubing lining made of iron tubing with an inter-rib niches often appears during shaft renovation and repairs. For such sealing, the Przedsiębiorstwo Budowy Szybów S.A. uses a sealing method by making a closed circumference groove around the sealed area in the internal shaft wall, whereas the groove depth must be smaller than the tubing depth. Then the sealing element is placed in the groove and pressed with spatial insert closed in the top side and having a hole for the injection of the sealing medium. In the next stage, the insert is mounted to the lining and then the sealing medium is injected in. When the process is finished, the insert hole is closed.

A specially designed milling machine is used for making grooves in shaft tubing lining. The milling machine is composed of the power transmission system and a construction for tubing and advance mechanism mounting. A battery drill-driver is used as the milling machine driving system, and the whole device is mounted to the tubing with the use of specially designed guides with handles. A model of the tubing milling machine is shown in Figure 3 . 


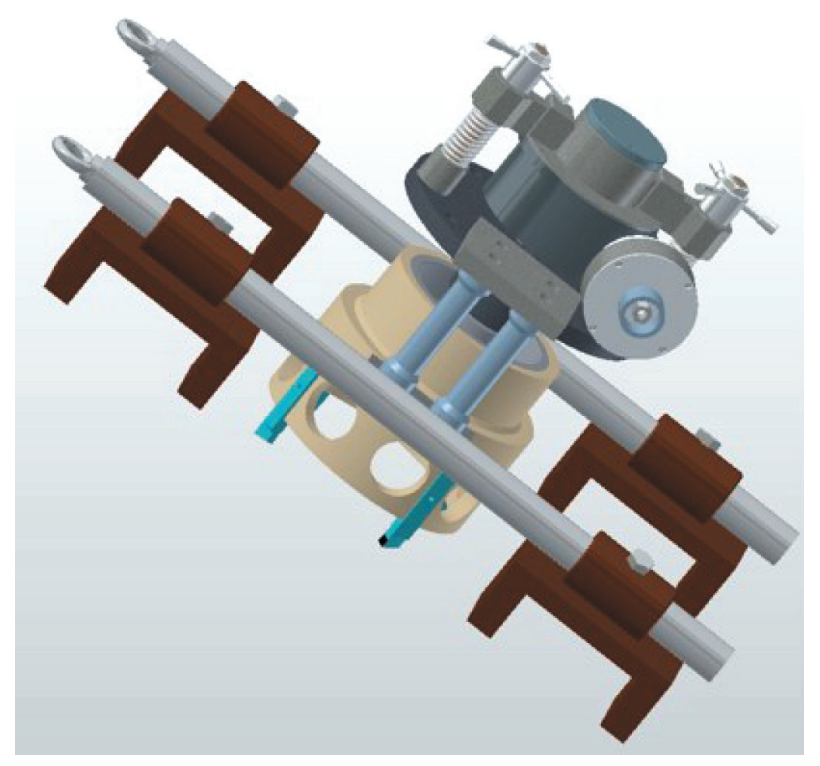

Fig. 3. Model of the tubing milling machine

\subsection{Tubing milling machine}

\subsubsection{Performance and technical data}

The described device is designed for shaft tubing lining and is used during the renovation and repairs of shafts, particularly for the needs of the mining industry.
Use of the milling machine allows the solution of technical problems occurring during repairs to the iron tubing lining of the shaft made of cast iron tubings.

The application of the milling machine allows the development of the new method of tubing shaft lining, comprising suitable stages for mounting the sealing insert in the tubing and the injection of the sealing medium. The new method comprises milling a closed circumference groove in the internal shaft lining, whereas the groove depth must be smaller than the tubing thickness. Then the sealing element is placed in the groove and pressed with a spatial insert with a hole for the injection of the sealing medium. In the next stage, the spatial insert is mounted to the shaft lining and then the sealing medium is injected to the sealed area via a hole in the spatial insert, before the insert hole is corked. A method for mounting the milling machine to the tubing is shown in Figure 4.

The milling machine is composed of a driving system, a construction used for mounting the milling machine on the tubing and an advance mechanism.

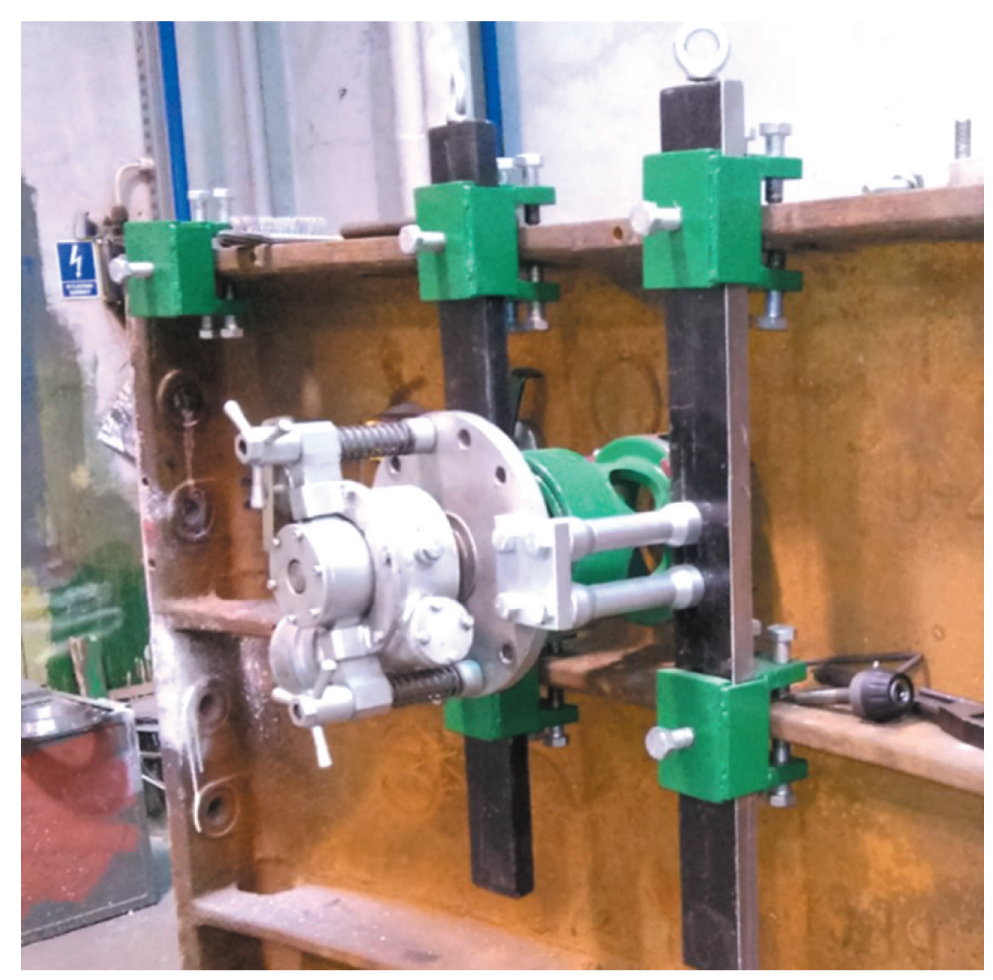

Fig. 4. Milling machine mounted to tubing

A Bosch battery grill-driver drives the central shaft of the epicyclic gear (planetary wheel). Then the movement is transferred from the central wheel into satellites connected in a single shackle via an immobile wheel with inner teeth. The planetary gear ratio amounts to $68 / 11$. The rotating shackle drives the 
worm shaft which in turn drives the worm wheel with a ratio of $40 / 1$, whereas the worm wheel is permanently connected to a rotary mandrel on which the milling machine head will be mounted. The indicative rotation of the drill-driver on the first run amounts to a maximum of $420 \mathrm{rpm}$, and on the second run the rotation amount is $1800 \mathrm{rpm}$.

The advance mechanism comprises a mandrel with a cut metric threading of $16 \mathrm{~mm}$ with a lead of $1.5 \mathrm{~mm}$. A single revolution of the advance mechanism knob results in a $1.5 \mathrm{~mm}$ jump of the milling head displacement. Maximal displacement of the milling head amounts to $25 \mathrm{~mm}$. The total ratio of the milling head amounts to 247,3 . The device is mounted on the tubing with specially designed handles. The construction should be covered with an anti-corrosion coating according to documentation recommendations. The total weight of the device amounts to $90.5 \mathrm{~kg}$.

\section{Driving system of the Bosch grill-driver:}

- Type

GSR 36 VE-2-Li.

- Catalogue No $06019 \mathrm{C} 0100$.

- Battery voltage $36 \mathrm{~V}$.

- Max torque $100 \mathrm{Nm}$

- Rotation 0-420 rpm (run 1), 0-1800 rpm (run 2).

- Mass with battery

- Worm gear ratio

- Planetary gear ratio

- Milling head picks ISO 42012 K20 - 4 piece (ISO 7 P/L 2012 K20 - 2 piece L, 2 piece P).

- Milling head advance mechanism.

- Manual drive, threaded screw M16×1.5 with knob.

- Advance $\quad 1.5 \mathrm{~mm}$ per 1 rotation.

- Mass of the whole machine depends on the chosen equipment version.

Mass of individual sub-assemblies see Table 1.

\subsubsection{Milling machine construction}

The milling machine body comprises a main plate with bearings cooperating with a rotary mandrel. The rotary mandrel cooperating with the main plate is connected on one side with a worm gear and advance system, whereas the other side is connected with a threaded sleeve on which a milling head is mounted.

The machine is driven by a Bosch grill-driver GSR 36 VE-2-Li f-my Bosch via a planetary gear haft, and then via a reductive ring onto a worm gear. From the worm gear, rotary movement is transferred onto a rotary mandrel connected via a sleeve with a milling head. In the planetary gear, rotations are transferred from the planetary reduction gear onto satellites joined in a single shackle. The external toothed wheel is immobilised and the mine plate is immobilised with two mounting elements with guides and four handles. The handles are located on tubing ribs. The milling machine is immobilised by guide and handles. Milling machine construction is presented in Figure 5, and its individual elements are show in Figure 6.

Before machine operation, and after the milling machine is mounted with the use of guides, the machine must be protected against inertial movement by hanging the machine with the use of a chain. The chain should be led via handle ears on guides, and then the chain should be mounted to a fixed element of construction in the mine shaft.

Milling is conducted with the use of four lathe tools of the ISO 42012 K20 type. Alternatively, in case of increased milling resistance, two left and two right tools of the ISO 7 P/L 2012 K20 type (Fig. 7) can be mounted alternately in milling head, but only for preliminary milling. After preliminary milling the ISO 7 tools should be replaced with ISO 4 ones, and the final groove milling should be executed.

Table 1

Mass of individual sub-assemblies

\begin{tabular}{|l|c|}
\hline Main plate with rotary mandrel, threaded sleeve, hub with pick guides with planetary and worm gears - no. 1,3,4,5,7 & $40 \mathrm{~kg}$ \\
\hline Round guides with fastening devices (set 2 piece) - item 6 & $54 \mathrm{~kg}$ \\
\hline Rectangular guides with fastening devices (set 2 piece) - item 6 & $74.2 \mathrm{~kg}$ \\
\hline Milling head for groove $\varnothing 178-154$ with tools - item 2 & $9.6 \mathrm{~kg}$ \\
\hline Milling head for groove $\varnothing 220-196$ with tools - item 2 & $10.7 \mathrm{~kg}$ \\
\hline Milling head for groove $\varnothing 246-222 \mathrm{~L}=190 / 120$ with tools - item 2 & $12.7 \mathrm{~kg}$ \\
\hline Milling head for groove $\varnothing 246-222 \mathrm{~L}=250 / 180$ with tools - item 2 & $16.2 \mathrm{~kg}$ \\
\hline
\end{tabular}




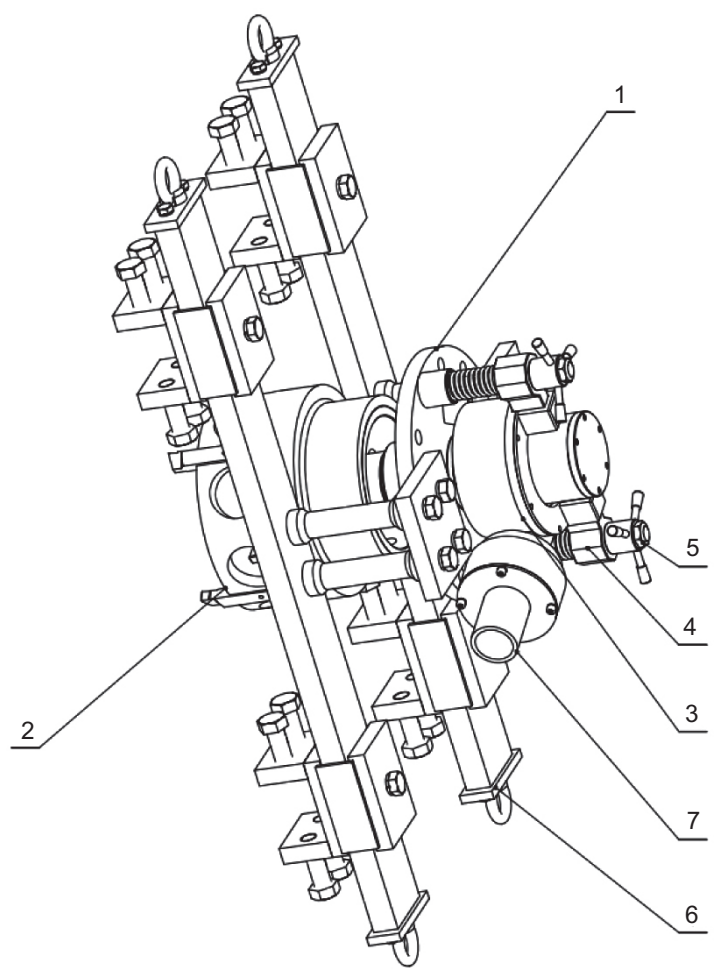

Fig. 5. Milling machine construction: 1 - main plate with mandrel and threaded sleeve; 2 - milling head - depending on the chosen option: • for groove $\varnothing 178-154$ for seal $\varnothing 176 / \varnothing 156$, • for groove $\varnothing 220-196$ for seal $\varnothing 218 / \varnothing 198$,

- for groove Ø246-222 for seal Ø244/Ø224 L = 190/120, • for groove Ø246-222 for seal Ø244/Ø224 L = 250/180;

3 - worm gear, 4 - hub with guides and mounting device, 5 - mounting to main plate device, 6 - guides with mounting - depending on the chosen option: • round for mounting milling machine with handles,

- rectangular for mounting the milling machine with handles; 7 - planetary gear with driving system housing
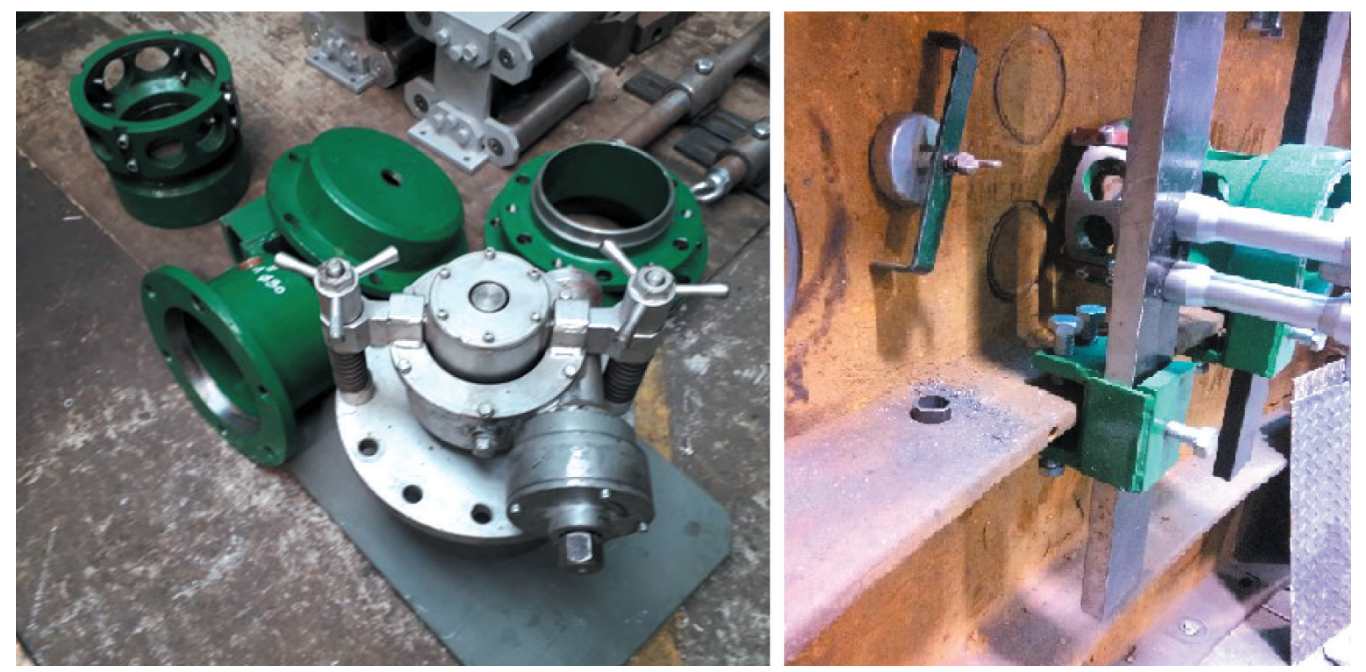

Fig. 6. Elements of milling machine

\begin{tabular}{|l|c|c|c|c|c|}
\hline $\begin{array}{c}\text { Nóż } \\
\text { Tool } \\
\text { Рeзец }\end{array}$ & $\begin{array}{c}\text { ISO 243 } \\
\text { ISO 514 } \\
\text { (PN-931M-58355) }\end{array}$ & $\frac{\text { PN-91 }}{\text { M-58352 }}$ & DIN & F & Gost \\
\hline ISO4 & NNPd & 4976 & 304 & 2120 \\
\hline & ISO7 & NNPa-C & 4981 & 307 & 2130 \\
\hline
\end{tabular}

Fig. 7. Tools mounted in the milling head 


\subsubsection{Exemplary technological process}

An example of the groove making process in the tubing shaft lining is described below:

1. groove diameter must be chosen and then a suitable milling machine head selected and mounted to the machine;

2. milling machine is mounted on guides;

3. handles with guides and milling machine are mounted (Fig. 8);

4. milling machine is positioned in a suitable location;

5. screws blocking the rotation of guides are loosened (refers only to round guides);

6. turning the guide distances of opposite blades according to the tubing surface (refers only to round guides);

7. bolts blocking the rotation of guides in the handles are screwed in place;

8. the milling machine mounted to the tubing lining is positioned at a distance of $2-5 \mathrm{~mm}$ from its surface with the use of bolts M16×1.5;
9. suitable run of the drill-driver (run 1 is recommended), rotation direction and value of torque (Maximal value is recommended) are set;

10. drill-driver GSR $36 \mathrm{VE}-2-\mathrm{Li}$ is connected with a planetary gear shaft and then the drill-driver rotation is switched on;

11. with the use of the milling machine head, the groove in the tubing lining is milled to the target depth with the use of a manual advance system, turning the knob M16×1.5; (to assure the proper operation of the tools, the adjustment should be made by turning the knobs simultaneously);

12. after grooving is finished, the drill-driver should be switched off - and the drill-drives should be disconnected from the milling machine;

13. after checking that the groove dimensions are suitable, the milling machine with guides and handles should be dismounted from the tubing lining. If the groove dimensions need to be corrected, the procedure described above should be repeated.

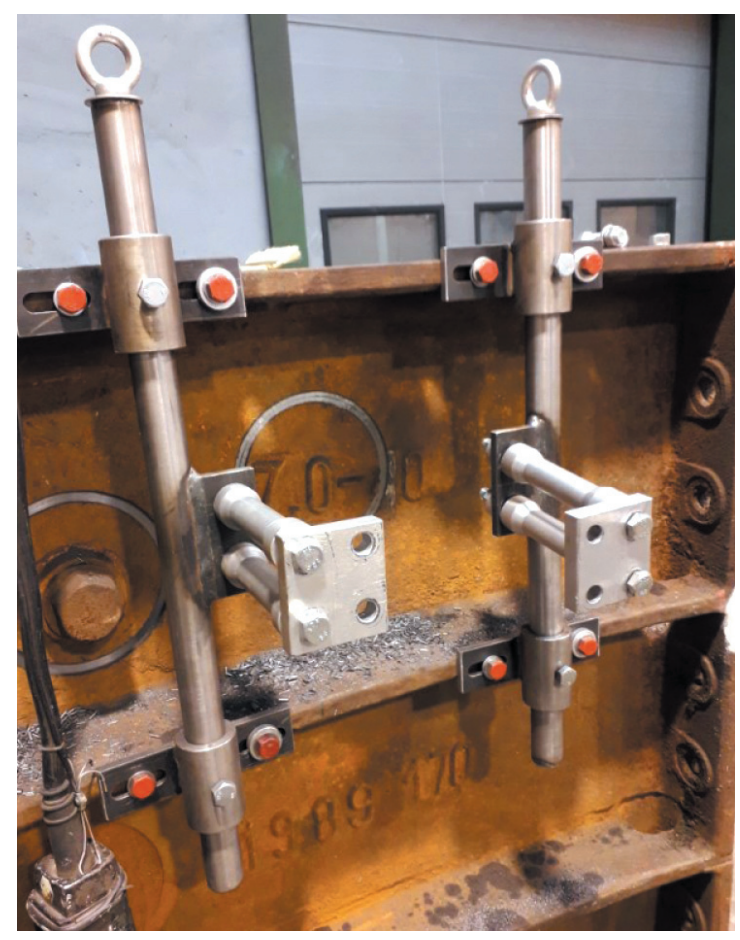

Fig. 8. Handles and guides

When the grooving is finished, mounting holes with a depth smaller than the tubing thickness are drilled at its external side with the use of a special matrix (the shape of the matrix is tailored to the shape of the groove in the tubing). Then the holes are threaded (a matrix having a shape tailored to the shape of the groove in the tubing can also be used for exact threading). A previously prepared lead seal is placed in the groove. The mounting procedure of the milling machine during tests conducted on the surface is shown above (Figs. 9 and 10).

When the seal is placed in groove, a spatial insert in form of closed at the top cylinder with a mounting flange with holes and a special hole for the injection of the sealing medium are mounted to the tubing. The lower part of the cylinder is inserted into the 
groove milled in the tubing in order to press the seal. The cylinder (Fig. 12) is mounted to the tubing with bolts inserted into the boreholes and then screwed in place. When the cylinder is screwed to the tubing, a sealing medium infilling the internal space of the insert is injected into the tubing in order to seal the fracture. When the sealing medium injection is finished, the injection hole is corked.
In order to assure the proper operations of the milling machine, it should be transported in a horizontal position on a transport pallet, with the use of a fork lift. In the case of machine transport with the use of the hosting crane, special transport handles should be screwed to the guides. Each time, all of the elements of the milling machine must be protected against damage.
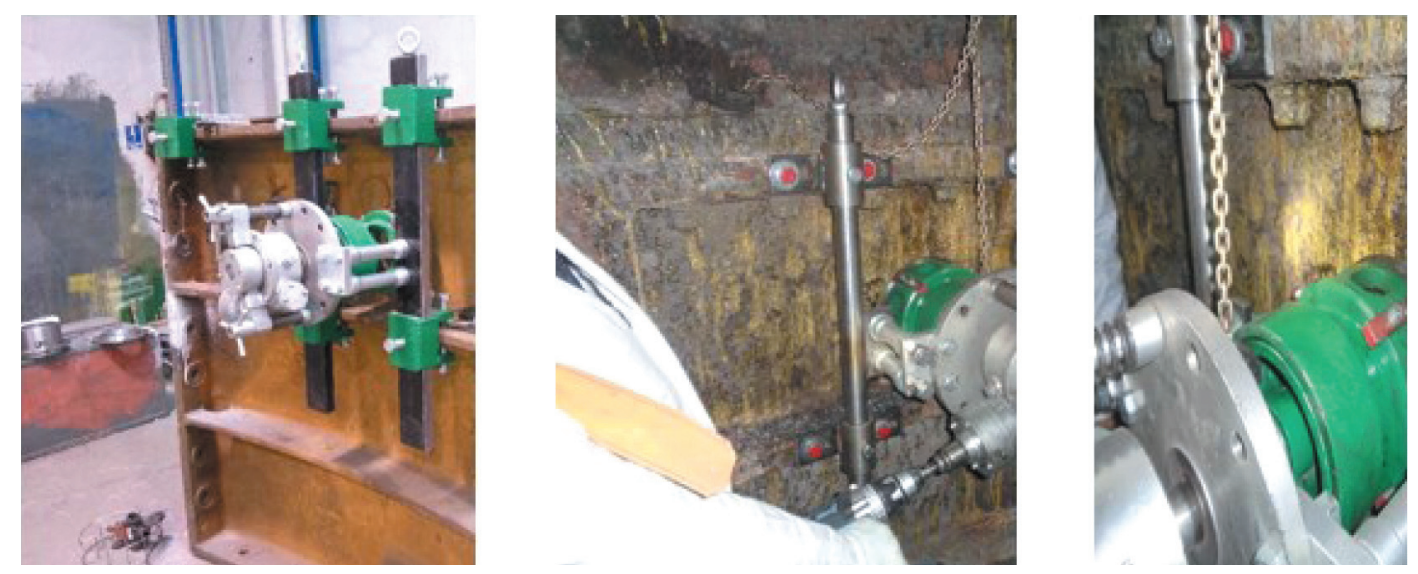

Fig. 9. Milling machine during tests made at the surface

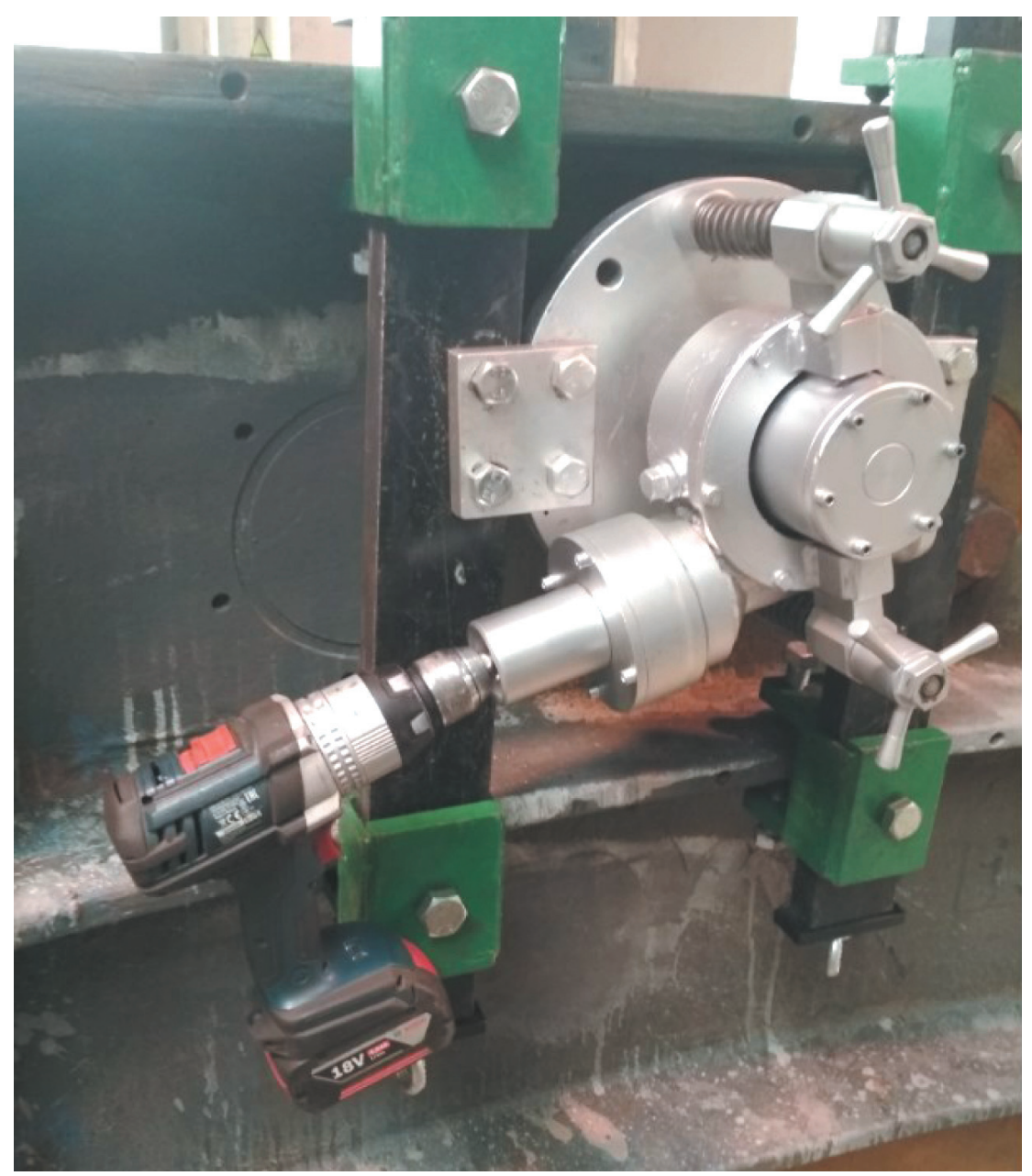

Fig. 10. Milling machine mounted to tubing lining with drill-driver driving the system 

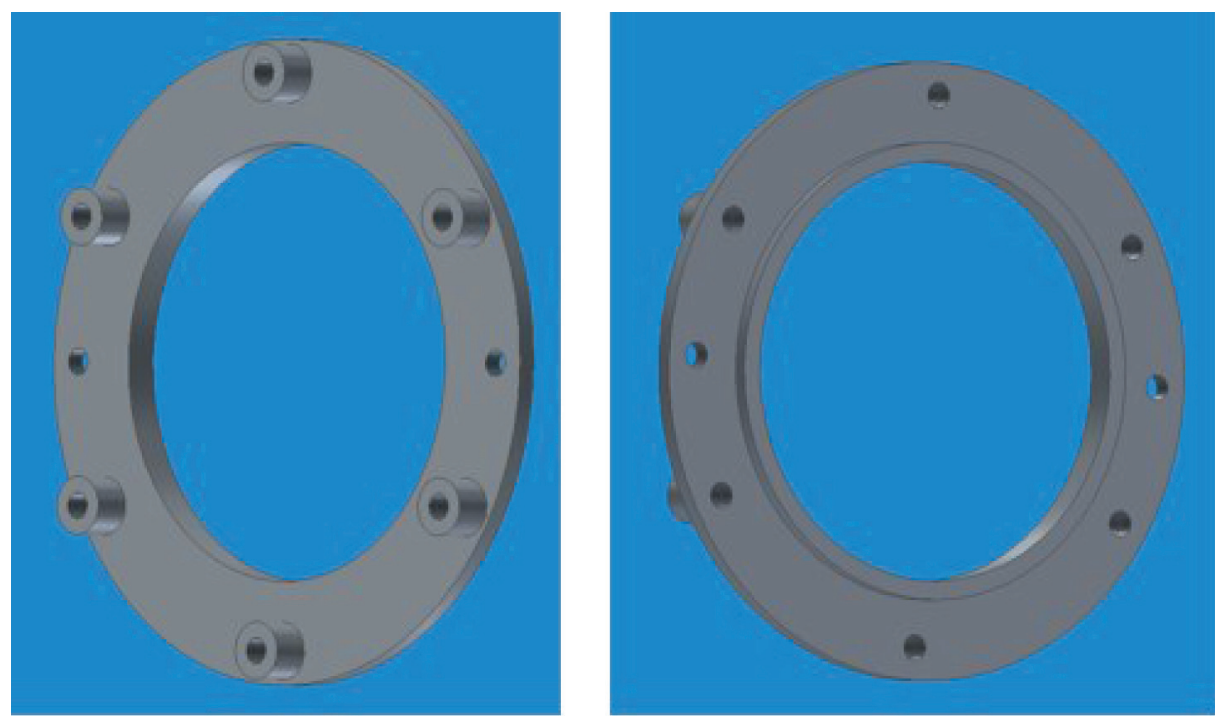

Fig. 11. Matrix used for borehole making

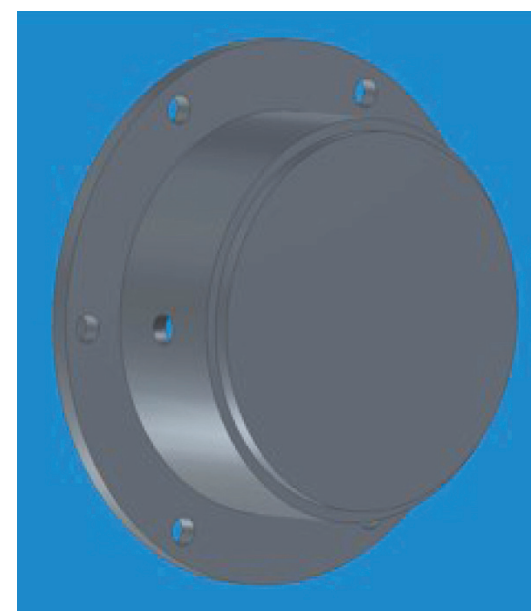

Fig. 12. Cylinder for the injection of the sealing medium
In the mine shaft, transport in a horizontal position is recommended. However, if the transport space is limited, transport in a vertical position is acceptable, taking care to maintain its stable position. The following machine subassemblies are recommended to be transported separately:

- guides with mounting elements,

- milling heads,

- main plate with rotary mandrel, threaded sleeve, hub with knife guides with mounting elements of main plate and planetary and worm gears. A transport basket should be used for the main plate transportation, as shown in Figure 13.

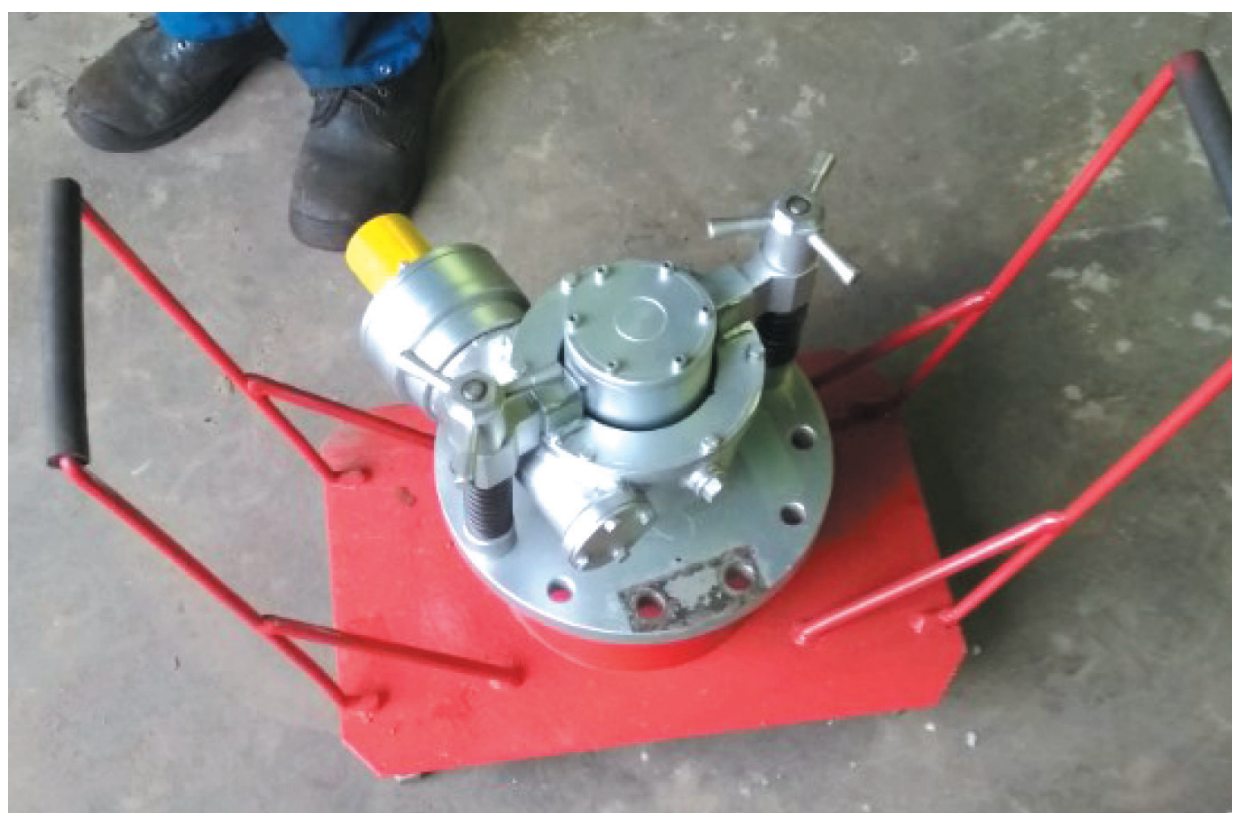

Fig. 13. Basket used for the milling machine transport 


\subsubsection{Certification}

The milling machine, designed and manufactured by Przedsiębiorstwo Budowy Szybów, is equipped with all of the requisite certificates allowing its opera- tions in explosion hazard environments, and machine construction is compatible with directives of the European Union - 2006/42/WE.

The identification plate of the described machine is shown in Figure 14.

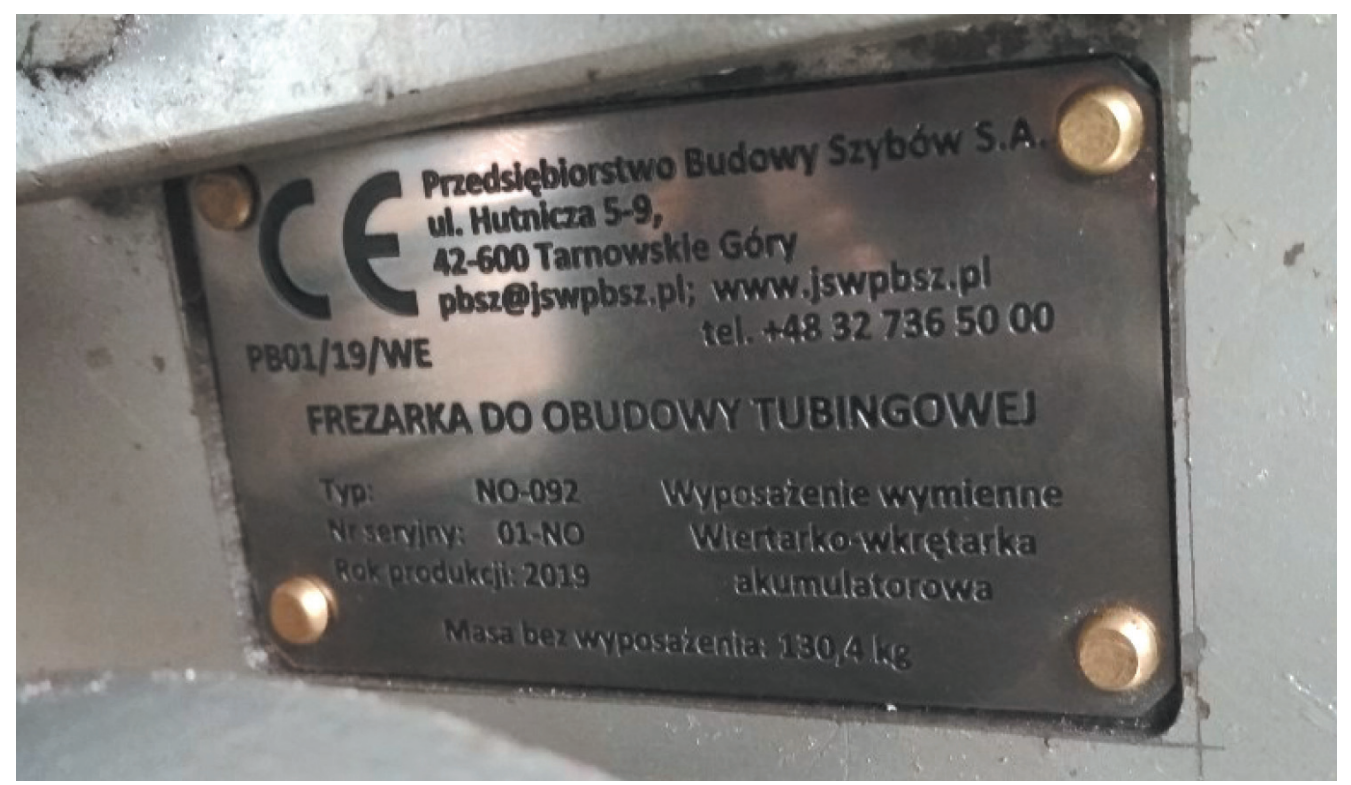

Fig. 14. Identification plate

\section{SUMMARY}

The sealing method of the tubing lining proposed by the Przedsiębiorstwo Budowy Szybów S.A. is an innovative solution and the application of this method facilitates the repair process, as well as solving numerous technological problems accompanying repairs of this type. In addition, this device possesses all of the required certificates assuring operational safety.

Application of the milling machine for tubing renovation (related to sealing) allows the considerable reduction of time needed for repair, also leading to shortening the time of the mine shaft technical stopover.

\section{References}

[1] Kostrz J.: Gtębienie szybów, Biblioteka Szkoły Eksploatacji Podziemnej, Kraków 2014

[2] Fabich S., Kokot B., Kulicki J., Szlązak M.: Obudowa tubingowa szybów w LGOM: przyczyny uszkodzeń obudowy, stosowana profilaktyka zapobiegania uszkodzeniom oraz metody napraw, "Górnictwo i Geoinżynieria" 2007, 3: 113-125.

[3] Wang L., Cheng Y.P., Ge C.G., Chen J.X., Li W., Zhou H.X., Wang H.F.: Safety technologies for the excavation of coal and gas outburst-prone coal seams in deep shafts, "International Journal of Rock Mechanics and Mining Science" 2013, 57: 24-33.
[4] Chmielewski J., Lekan W., Głuch P.: Nowe rozwiazania obudowy głowic zbiorników retencyjnych $w$ warunkach $L W$ "Bogdanka" SA, "Budownictwo Górnicze i Tunelowe" 2012, 3: 39-47.

[5] Czaja P., Kamiński P.: Wybrane zagadnienia techniki i technologii głębienia szybów Biblioteka Szkoły Eksploatacji Podziemnej, Kraków 2016.

[6] Kamiński P. Cholewa M.: Technologia i organizacja robót wymiany obudowy szybu Pótnocny II KWK Halemba, Tarnowskie Góry 2018 [unpublished].

TOMASZ CICHOŃ M.Sc., Eng. KRZYSZTOF PYREK KRYSTIAN RATUSZY M.Sc., Eng. PIOTR KALINOWSKI M.Sc., Eng. Przedsiębiorstwo Budowy Szybów S.A. ul. Hutnicza 5-9, 42-600 Tarnowskie Góry, Poland \{tcichon, kpyrek, kratuszny, pkalinowski\}@.jswpbsz.pl

PAWEŁ KAMIŃSKI Ph.,D., Eng. Przedsiębiorstwo Budowy Szybów S.A. ul. Hutnicza 5-9, 42-600 Tarnowskie Góry AGH University of Science and Technology ul. Mickiewicza 30, 30-059 Kraków, Poland pkaminski@jswpbsz.pl,pkamin@agh.edu.pl 
TOMASZ CICHOŃ

KRZYSZTOF PYREK

KRYSTIAN RATUSZNY

PIOTR KALINOWSKI

PAWEŁ KAMIŃSKI

\title{
Frezarka do wykonywania rowków w obszarze wnęki międzyżebrowej tubingów
}

\begin{abstract}
Konieczność wykonania uszczelniania tubingowej obudowy szybu, wykonanej z tubingów żeliwnych w obszarze ich wnęki międzyżebrowej, pojawia się często przy wykonywanych remontach i naprawach obudowy szybów. W obszarze poszczególnych tubingów obudowy szybu moga pojawiać się przecieki bądź rysy czy pęknięcia. Przedsiębiorstwo Budowy Szybów S.A. stosuje do wykonania takiego uszczelnienia metodę polegająca na tym, że wokót uszczelnianego obszaru w obudowie od wnętrza szybu wykonuje się rowek o zamkniętym obwodzie i o głębokości mniejszej niż grubość samego tubingu. Następnie $w$ rowku umieszcza się element uszczelniający, który dociska się przestrzenna wkładka zamknięta od góry i zaopatrzona w otwór do wttaczania medium uszczelniajacego. Do wykonania rowków (gniazd do mocowania uszczelnienia) w obudowie tubingowej zabudowanej $w$ szybie kopalnianym stuzy specjalnie do tego celu zaprojektowana frezar$k a$. Frezarka składa się z układu napędowego oraz z konstrukcji mocujacej frezarkę do tubingu oraz mechanizmu posuwu. Napęd frezarki stanowi wiertarkowkrętarka akumulatorowa, a cate urzadzenie mocowane jest do tubingu za pomoca specjalnie zaprojektowanych prowadnic z uchwytami.
\end{abstract}

Słowa kluczowe: frezarka do tubingów, naprawa obudowy szybu, obudowa tubingowa

\section{WPROWADZENIE}

Obudowa tubingowa jest stosowana jako obudowa ostateczna szybów głębionych w trudnych warunkach hydrogeologicznych stanowi ją cylinder złożony z oddzielnych pierścieni. Poszczególne pierścienie składają się z oddzielonych, jednakowych segmentów zwanych tubingami. Tubingi mogą być wykonywane z żelbetu, żeliwa, staliwa i ze stali. Tubingi stalowe, których wymiary są uzależnione od średnicy szybu, tworzą po zabudowaniu metalową rurę [1].

\subsection{Przyczyny i przykłady uszkodzeń obudowy tubingowej}

W obszarze poszczególnych tubingów tworzących obudowę wyrobiska mogą pojawiać się przecieki, rysy oraz pęknięcia. Są to uszkodzenia obudowy szybu wymagające naprawy. Najczęstszą przyczyną powstawa- nia tego typu zmian są wady materiałowe, warunki hydrogeologiczne panujące w otaczającym górotworze oraz oddziaływanie górotworu na obudowę.

W rejonie Górnośląskiego Zagłębia Węglowego obudowa tubingowa jest stosowana sporadycznie przede wszystkim ze względu na aspekty ekonomiczne. Zdecydowanie większą liczbę odcinków szybów górniczych wykonanych w stalowej obudowie tubingowej możemy zaobserwować w kopalniach KGHM w Legnicko-Głogowskim Okręgu Miedziowym. W latach dziewięćdziesiątych XX wieku w szybach LGOM zaobserwowano pierwsze uszkodzenia żeliwnych segmentów tubingowych w szybie L-II kopalni Lubin. Uszkodzenia objęły segmenty obudowy tubingowej pierścienia pikotażowego górnego oraz dolnego, szczeliny pikotażowej posadowionej na głębokości 295,8 m ( 50 m powyżej spągu utworów trzeciorzędowych). Uszkodzenia polegały na wyłamaniu kołnierzy poziomych, sąsiadujących bezpośrednio ze szczeliną pikotażową, co przedstawiono na rysunku $1[2,3]$. 

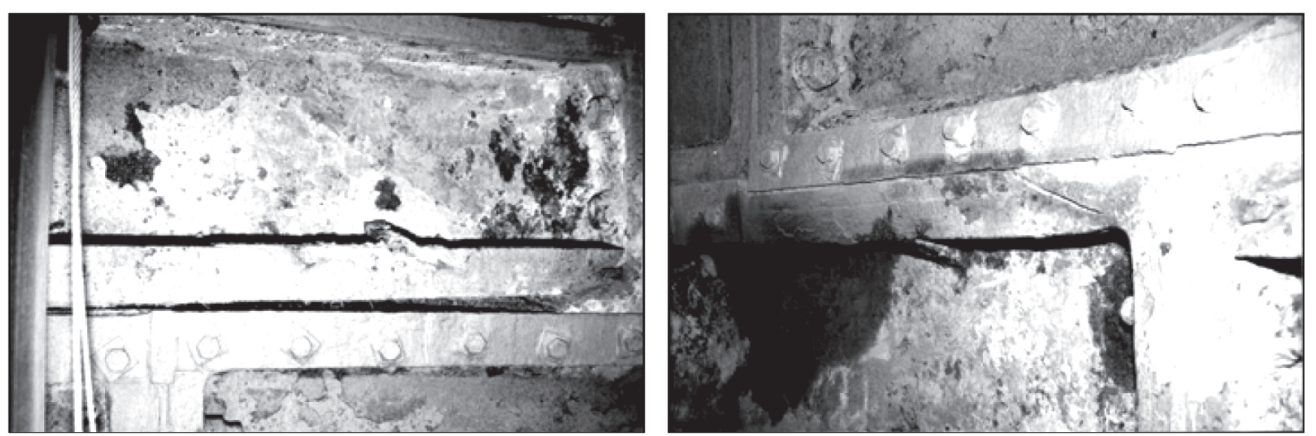

Rys. 1. Uszkodzenia segmentów tubingowych szczeliny pikotażowej nr 8 w szybie L-II kopalni Lubin [2]
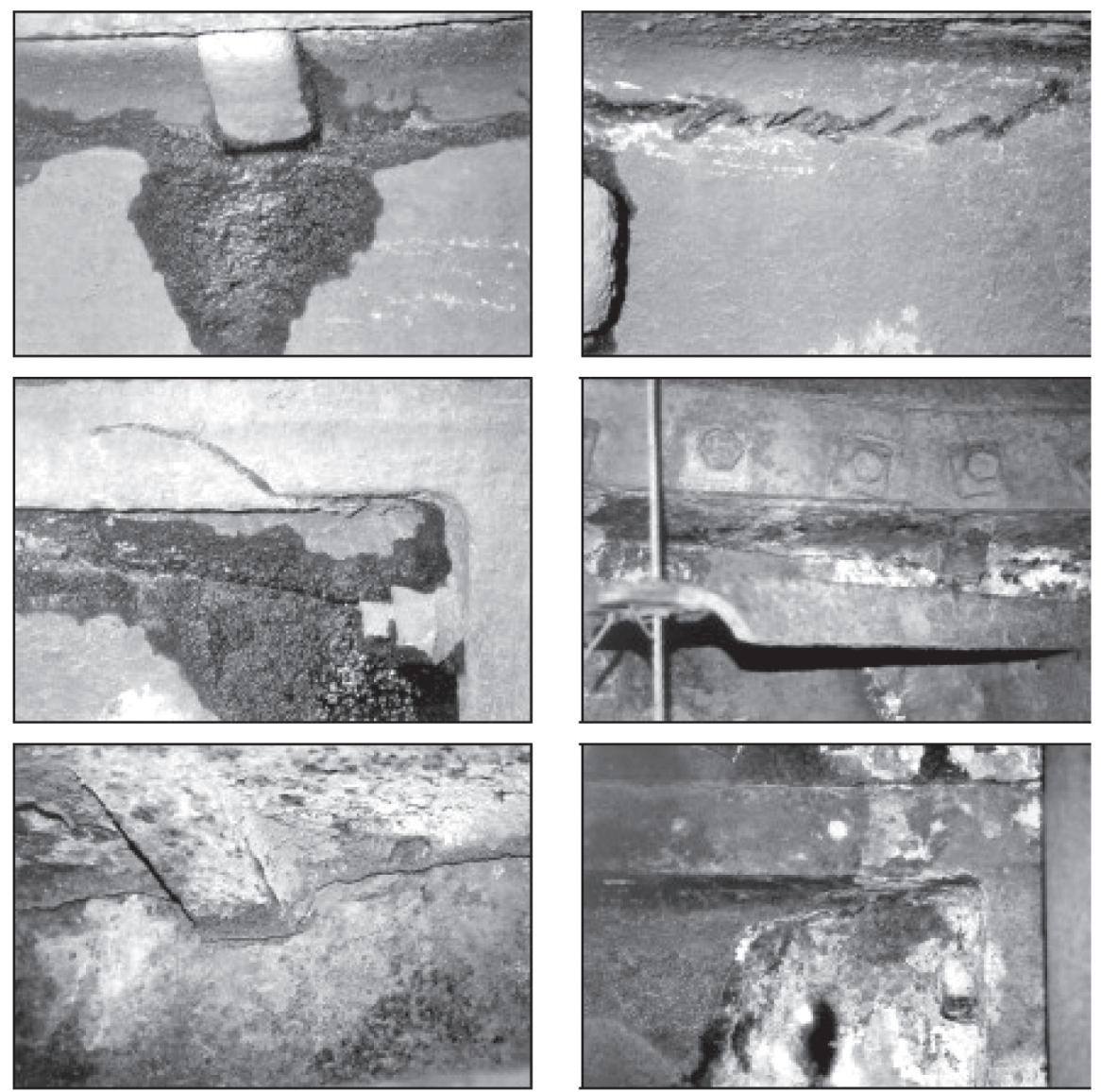

Rys. 2. Uszkodzenia segmentów tubingowych szybów LGOM w rejonach szczelin pilotażowych [2]

Podczas licznych rewizji obudowy rury szybowej prowadzonych w kopalniach należących do KGHM we wszystkich szybach stwierdzono mniej lub bardziej groźne zniszczenia obudowy. Przykłady zniszczeń przedstawiono na rysunku 2.

Na podstawie obserwacji i analizy zniszczeń stwierdzono, że wszystkie uszkodzenia łączą następujące czynniki:

- występowanie uszkodzeń w większości pierścieni tubingowych zabudowanych bezpośrednio na szczelinach pikotażowych,

- w większości przypadków pierwsze uszkodzenia w danym szybie dotyczą segmentów tubingowych zabudowanych na szczelinach pikotażowych położonych w rejonie spągu utworów trzeciorzędowych,
- wzrost liczby uszkodzonych tubingów w danym pierścieniu wraz z upływem czasu,

- tendencja do pojawiania się uszkodzeń segmentów na sąsiednich szczelinach pikotażowych,

- brak spękań segmentów tubingowych zabudowanych na szczelinach pikotażowych posadowionych w skałach zwięzłych,

- poza jedynym stwierdzonym przypadkiem uszkodzenia tubingów nie były spowodowane wadami materiałowymi [2].

Problemy związane z uszkodzeniami obudów tubingowych, zwłaszcza w obszarze wnęki międzyżebrowej, nie dotyczą jedynie kopalń i szybów należących do KGHM. Znane są przypadki zniszczeń obudowy tubingowej w ko- 
palniach węgla kamiennego, np. szyb VII KWK, Chwałowice, zbiornik retencyjny w LW Bogdanka, szyb północny II KWK Ruda Ruch Halemba itp. [4-6].

\subsection{Sposoby zabezpieczeń obudowy tubingowej}

Uszkodzenie obudowy tubingowej zagraża bezpieczeństwu ich funkcjonowania w sposób bezpośredni, gdyż prawie zawsze podczas szeroko rozumianych zniszczeń, np. pęknięć, towarzyszy mu dopływ wody (w mniejszym lub większym stopniu) do szybu. Bezpieczeństwo wyrobisk górniczych uznaje się za zagrożone, gdy zniszczenie obudowy obejmie szerszą strefę i wskutek znacznego wypływu wody dochodzi do ruchów górotworu - wtedy możliwość zagrożenia bezpieczeństwa staje się bardziej realna.

\subsubsection{Sposoby zabezpieczenia}

Analizując zniszczenia i deformacje obudowy rury szybowej, należy założyć, że jest to proces, który będzie postępował. Na zmianę stanu naprężeń w obudowie, jej odkształcenia i w konsekwencji zniszczenia oprócz wad materiałowych może mieć wpływ deformacja górotworu.

$\mathrm{Z}$ tego powodu ważne jest stosowanie działań profilaktycznych, które powinny ograniczyć ilość i wielkość zniszczeń obudowy. Podstawowe działania profilaktyczne można określić jako:

- dobór odpowiedniego systemu eksploatacji złoża w pobliżu filarów granic filarów ochronnych;

- przygotowanie kolumny tubingowej na bezpieczne przejmowanie wpływów od prowadzonej eksploatacji - tu realizowane są rozwiązania obejmujące:

- wzmocnienie obudowy w szybach w rejonach szczelin pikotażowych przez wypełnienie zbrojonym tworzywem przestrzeni międzyżebrowych przylegających bezpośrednio do szczeliny pikotażowej,

- upodatnienie kolumn tubingowych na szczelinach pikotażowych przez odwiercenie otworów w drewnianym wypełnieniu szczeliny (ze względów bezpieczeństwa długość otworów nie może być większa niż szerokość kołnierza) [5].

\subsubsection{Sposoby uszczelnienia obudowy tubingowej - polskie opisy patentowe}

Na podstawie polskich zgłoszeń patentowych możemy wyróżnić trzy metody wzmacniania obudowy tubingowej szybów górniczych. Polskie zgłoszenie patentowe P.361415 opisuje sposób wzmocnienia uszkodzonych segmentów obudowy tubingowej, gdzie w prze- strzeni międzyżebrowej tubingów zabudowuje się klatki zbrojeniowe. Tak przygotowana przestrzeń międzyżebrowa wypełniana jest tworzywem wzmacniającym.

Inne rozwiązanie przedstawia opis PL 179822 B1, który zawiera sposób uszczelniania i naprawy tubingów górniczych w obszarze wnęki międzyżebrowej. W tym sposobie w pierwszej kolejności w rejon występowania przecieku zatłaczane jest medium uszczelniające, co ma na celu zatrzymanie wypływu wody. Po zatrzymaniu przecieku na wewnętrzną powierzchnię tubingu nakładana jest warstwa kleju, do której dociskana jest metalowa wkładka. Sama metalowa wkładka ma zewnętrzny kształt lustrzanego odbicia wnęki tubingu i poza przyklejaniem jest dodatkowo mocowana śrubami do żeber i kołnierzy tubingów. Zasadniczo długość łukowa wkładki odpowiada długości łukowej wnęki między żebrami segmentu tubingu, jednak nie jest to obligatoryjne. Natomiast zawsze długość wkładki jest tak dobrana, żeby zapewniała wymaganą szczelność i wytrzymałość naprawianego segmentu.

\section{NOWY SPOSÓB USZCZELNIENIA OBUDOWY TUBINGOWEJ}

Jak wspomniano, konieczność wykonania uszczelniania tubingowej obudowy szybu, wykonanej z tubingów żeliwnych w obszarze ich wnęki międzyżebrowej pojawia się często przy wykonywanych remontach i naprawach obudowy szybów. Przedsiębiorstwo Budowy Szybów S.A. stosuje do wykonania takiego uszczelnienia metodę polegającą na tym, że wokół uszczelnianego obszaru w obudowie od wnętrza szybu wykonuje się rowek o zamkniętym obwodzie i o głębokości mniejszej niż grubość samego tubingu. Następnie w rowku umieszcza się element uszczelniający, który dociska się przestrzenną wkładką zamkniętą od góry i zaopatrzoną w otwór do wtłaczania medium uszczelniającego. W kolejnym etapie przestrzenną wkładkę mocuje się do obudowy, a następnie w uszczelniany obszar, poprzez otwór przestrzennej wkładki, wtłaczane jest wspomniane medium uszczelniające, po zakończeniu procesu otwór we wkładce zamyka się.

Do wykonania rowków (gniazd do mocowania uszczelnienia) w obudowie tubingowej zabudowanej w szybie kopalnianym służy specjalnie do tego celu zaprojektowana frezarka. Frezarka składa się z układu napędowego oraz z konstrukcji mocującej frezarkę do tubingu oraz mechanizmu posuwu. Napęd frezarki stanowi wiertarkowkrętarka akumulatorowa, a całe urządzenie mocowane jest do tubingu za pomocą specjalnie zaprojektowanych prowadnic z uchwytami. $\mathrm{Na}$ rysunku 3 przedstawiono model frezarki do tubingów. 


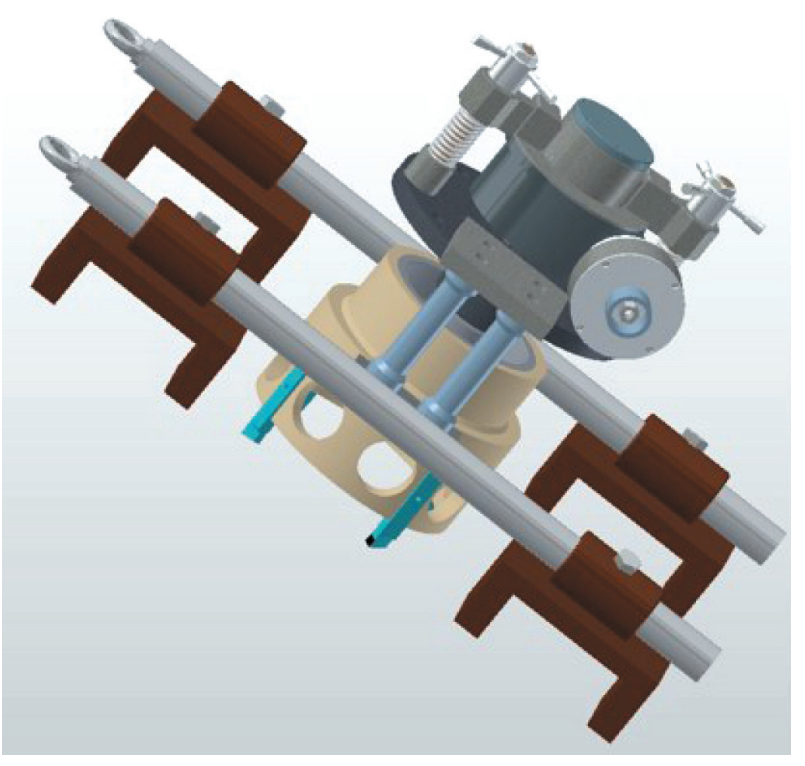

Rys. 3. Model frezarki do tubingów

\subsection{Frezarka do tubingów}

\subsubsection{Charakterystyka i dane techniczne}

Opisywane urządzenie jest przeznaczone do uszczelniania tubingowej obudowy szybu, znajduje zastosowanie podczas remontów i napraw obudowy szybów, zwłaszcza na potrzeby górnictwa. Zastosowanie frezarki umożliwi rozwiązanie problemu technicznego występującego przy naprawach tubingowej obudowy szybu, wykonanej zwłaszcza z tubingów żeliwnych.

Celem zastosowania frezarki jest rozwiązanie problemu technicznego występującego przy naprawach tubingowej obudowy szybu, wykonanej zwłaszcza z tubingów żeliwnych. Użycie frezarki pozwala na stworzenie nowego sposobu uszczelniania tubingowej obudowy szybu. Taki sposób uszczelniania polega na mocowaniu do tubingu wkładki uszczelniającej oraz zatłaczaniu medium uszczelniającego. Nowa technologia polega na tym, że wokół uszczelnianego obszaru w obudowie od wnętrza szybu wykonywany jest rowek o zamkniętym obwodzie i o głębokości mniejszej niż grubość samego tubingu. Następnie w rowku umieszczany jest element uszczelniający, który dociska się przestrzenną wkładką zamkniętą od góry i zaopatrzoną w otwór do zatłaczania medium uszczelniającego. W kolejnym etapie przestrzenna wkładka mocowana jest do obudowy, a następnie do uszczelnianego obszaru poprzez otwór przestrzennej wkładki, zatłaczane jest medium uszczelniające, a po zakończeniu zatłaczania otwór wewnątrz wkładki jest zamykany. Na rysunku 4 przedstawiono sposób zamocowania frezarki do tubingu.

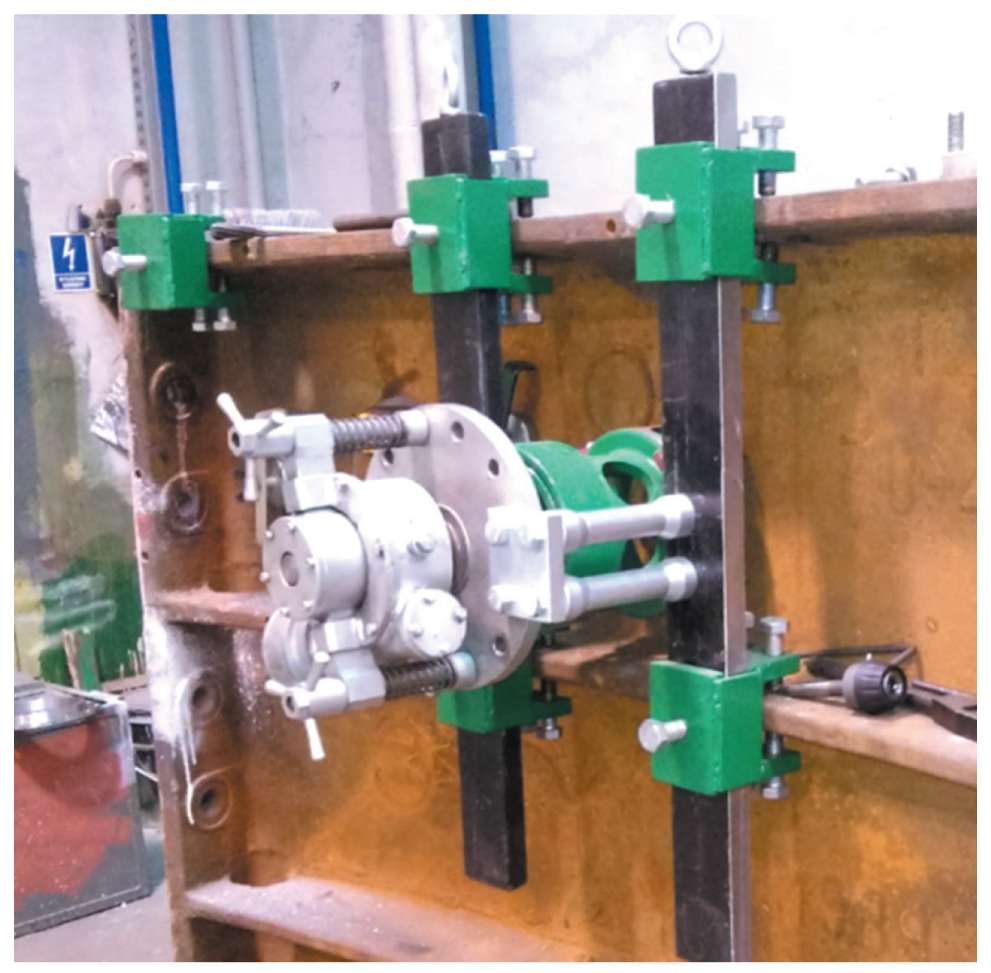

Rys. 4. Frezarka zamocowana do tubingu

Frezarka składa się z układu napędowego oraz $\mathrm{z}$ konstrukcji mocującej frezarkę do tubingu oraz mechanizmu posuwu.
Wiertarkowkrętarka akumulatorowa, np. firmy Bosch, napędza wałek centralny przekładni planetarnej (koło słoneczne). Następnie przez unieruchomio- 
ne koło o uzębieniu wewnętrznym moment przekazywany jest $\mathrm{z}$ koła centralnego na satelity połączone w jedno jarzmo. Przełożenie przekładni planetarnej wynosi 68/11. Jarzmo, obracając się, napędza wałek $\mathrm{z}$ naciętym ślimakiem. Ślimak napędza ślimacznicę w przełożeniu 40/1, natomiast ślimacznica połączona jest na stałe z trzpieniem obrotowym, na którym zamocowana będzie głowica frezarska. Obroty znamionowe wiertarkowkrętarki na pierwszym biegu wynoszą maks. $420 \mathrm{obr} / \mathrm{min}$, natomiast na drugim biegu wynoszą maks. $1800 \mathrm{obr} / \mathrm{min}$.

Mechanizm posuwu składa się z trzpienia $\mathrm{z}$ naciętym gwintem metrycznym $16 \mathrm{~mm}$ o skoku $1,5 \mathrm{~mm}$. Jeden obrót pokrętła posuwu powoduje przemieszczenie głowicy frezarskiej o $1,5 \mathrm{~mm}$. Maksymalne przemieszczenie głowicy frezarskiej wynosi $25 \mathrm{~mm}$. Całkowite przełożenie głowicy frezarskiej wynosi 247,3. Całe urządzenie mocowane jest do tubingu za pomocą specjalnie zaprojektowanych uchwytów. Całość konstrukcji należy pokryć powłoką antykorozyjną zgodnie z niniejszą dokumentacją. Ciężar całego urządzenia wynosi $90,5 \mathrm{~kg}$.

Napęd wiertarkowkrẹtarki akumulatorowej Bosch:

- Typ

GSR 36 VE-2-Li.

- Nr katalogowy $06019 \mathrm{C} 0100$.

- Napięcie zasilające $\mathrm{z}$ akumulatora

$36 \mathrm{~V}$.

- Maks. moment obrotowy $100 \mathrm{Nm}$

- Obroty 0-420 obr/min (bieg 1), 0-1800 obr/min (bieg 2).

- Masa z założonym akumulatorem $3,4 \mathrm{~kg}$.

- Przełożenie przekładni ślimakowej

- Przełożenie przekładni planetarnej

$6,18: 1$.

- Noże skrawające głowicy ISO 42012 K20 - 4 szt. (alternatywnie ISO 7 P/L 2012 K20 - 2 szt. L, 2 szt. P).

- Mechanizm posuwu głowicy.

- Napęd ręczny, śruba z gwintem M16×1,5 z pokręttem.

- Posuw $1,5 \mathrm{~mm} / 1 \mathrm{obr}$.

- Masę całego urządzenia należy przyjąć w zależności od wybranej wersji wyposażenia.

Masy poszczególnych podzespołów podano w tabeli 1 .

\subsubsection{Budowa frezarki}

Korpus frezarki stanowi ułożyskowana płyta główna współpracująca $\mathrm{z}$ trzpieniem obrotowym. Trzpień obrotowy współpracujący z płytą główną połączony jest jednym końcem $\mathrm{z}$ przekładnią ślimakową oraz mechanizmem posuwu, natomiast $\mathrm{z}$ drugiej strony połączony jest $\mathrm{z}$ tuleją gwintowaną, na której osadzona jest głowica frezarska.

Napęd przekazywany jest $\mathrm{z}$ wiertarkowkrętarki GSR 36 VE-2-Li firmy Bosch na wałek przekładni planetarnej, a następnie przez pierścień redukcyjny na przekładnię ślimakową. Z przekładni ślimakowej moment obrotowy przekazany jest na trzpień obrotowy połączony poprzez tuleję z głowicą frezarską. W przekładni planetarnej obroty przekazywane są z koła słonecznego na satelity połączone w jedno jarzmo. Koło o uzębieniu zewnętrznym jest unieruchomione. Płyta główna unieruchamiana jest za pomocą dwóch mocowań z prowadnicami, na których osadzone są cztery uchwyty, zaś uchwyty są osadzone na żebrach tubingów. Frezarka zostaje unieruchomiona przez uchwyty i prowadnice. Schemat frezarki został przedstawiony na rysunku 5, a elementy frezarki przedstawiono na rysunku 6.

Przed przystąpieniem do pracy należy po zamocowaniu frezarki za pomoca prowadnic dodatkowo zabezpieczyć ją przed ruchem bezwładnościowym przez podwieszenie jej za pomocą łańcucha. Łańcuch należy przekładać przez śruby z uchem występujące na prowadnicach, a następnie zamocować go do elementu stałego konstrukcji występującej w szybie górniczym.

Obróbka skrawaniem prowadzona jest za pomocą czterech noży tokarskich przecinaków typu ISO 42012 K20. Alternatywnie w przypadku zwiększonych oporów skrawania można zamiast ww. noży zastosować dwie sztuki noży lewych i dwie szuki noży prawych typu ISO 7 P/L 2012 K20 (rys. 7) zamocowanych naprzemiennie w głowicy frezarskiej, ale tylko do wykonania obróbki wstępnej. Po wykonaniu obróbki wstępnej należy wymienić noże ISO 7 na noże ISO 4 i za ich pomocą wykonać obróbkę rowka na gotowo.

Tabela 1

Masy poszczególnych podzespołów urządzenia

\begin{tabular}{|l|c|}
\hline $\begin{array}{l}\text { Płyta główna wraz z trzpieniem obrotowym, tuleją gwintowana, piastą z prowadnicami do prowadzenia noży } \\
\text { i mocowaniem układu do płyty głównej oraz z przekładniami planetarna i ślimakową - poz. } 1,3,4,5,7\end{array}$ & $40 \mathrm{~kg}$ \\
\hline Prowadnice okragłe z mocowaniem (kpl. 2 szt.) - poz. 6 & $54 \mathrm{~kg}$ \\
\hline Prowadnice prostokątne z mocowaniem (kpl. 2 szt.) - poz. 6 & $74,2 \mathrm{~kg}$ \\
\hline Głowica frezarska dla rowka $\varnothing 178-154$ wraz z nożami - poz. 2 & $9,6 \mathrm{~kg}$ \\
\hline Głowica frezarska dla rowka $\varnothing 220-196$ wraz z nożami - poz. 2 & $10,7 \mathrm{~kg}$ \\
\hline Głowica frezarska dla rowka $\varnothing 246-222 \mathrm{~L}=190 / 120$ wraz z nożami - poz. 2 & $12,7 \mathrm{~kg}$ \\
\hline Głowica frezarska dla rowka $\varnothing 246-222 \mathrm{~L}=250 / 180$ wraz z nożami - poz. 2 & $16,2 \mathrm{~kg}$ \\
\hline
\end{tabular}




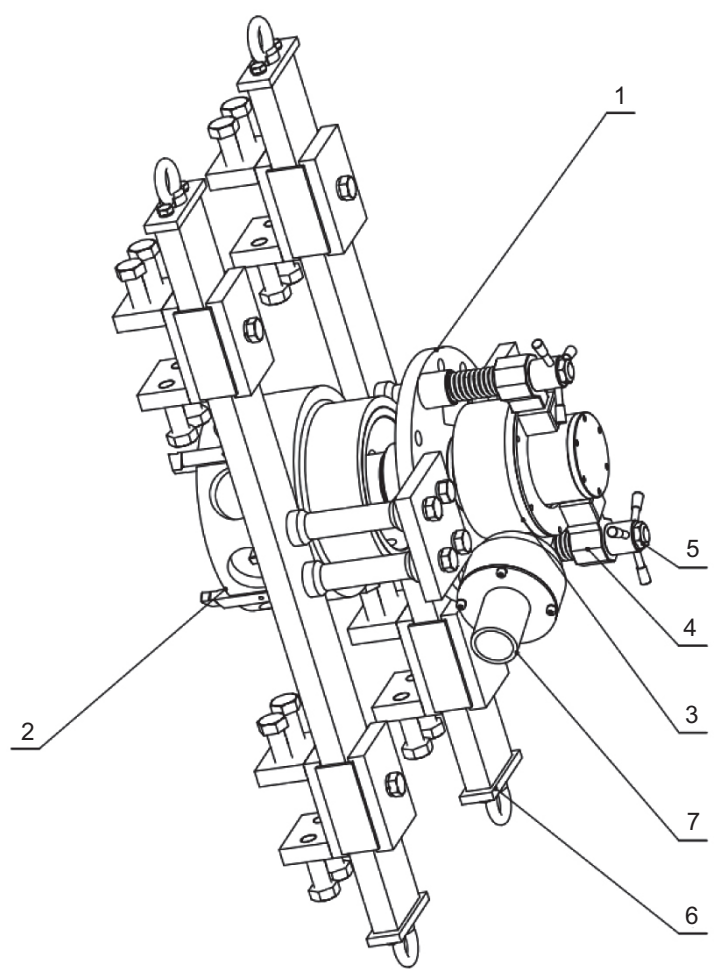

Rys. 5. Budowa frezarki: 1 - płyta główna wraz z trzpieniem i tuleją gwintową; 2 - głowica frezerska, w zależności od wybranego wariantu: • dla rowka Ø178-154 pod uszczelkę 176/156, • dla rowka Ø220-196 pod uszczelkę 218/198, • dla rowka Ø246-222 pod uszczelkę 244/224 L = 190/120, • dla rowka Ø246-222 pod uszczelkę 244/22 L = 250/180; 3 - przekładnia ślimakowa; 4 - piasta z prowadnicami i mocowaniem; 5 - mocowanie układu do płyty głównej; 6 - prowadnice wraz z mocowaniem - w zależności od wybranego wariantu: • okragłe do mocowania frezarki wraz z uchwytami, • prostokątne do mocowania frezarki wraz z uchwytami; 7 - przekładnia planetarna z ostona napędu
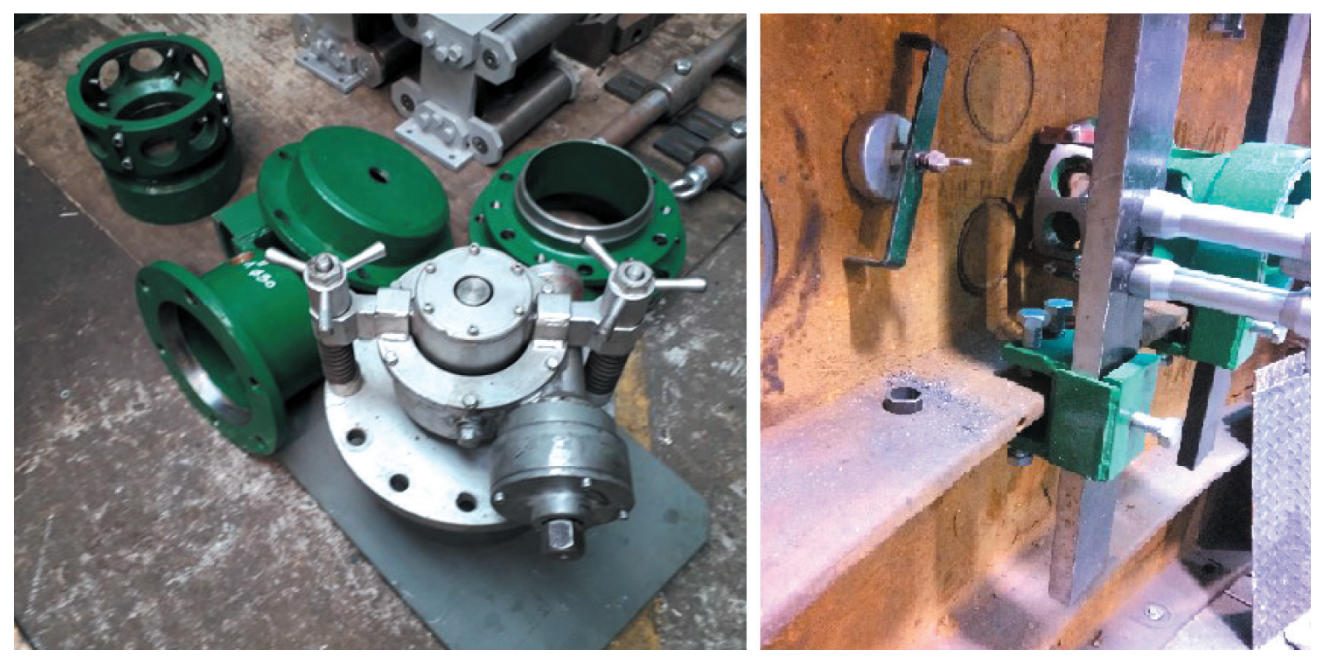

Rys. 6. Elementy frezarki

\begin{tabular}{|l|c|c|c|c|c|}
\hline $\begin{array}{c}\text { Nóż } \\
\text { Tool } \\
\text { Резец }\end{array}$ & $\begin{array}{c}\text { ISO 243 } \\
\text { ISO 514 } \\
\text { (PN-93м-58355) }\end{array}$ & $\frac{\text { PN-91 }}{\text { M-58352 }}$ & DIN & F & Gost \\
\hline ISO4 & NNPd & 4976 & 304 & 2120 \\
\hline & ISO7 & NNPa-C & 4981 & 307 & 2130 \\
\hline
\end{tabular}

Rys. 7. Noże tokarskie montowane w głowicy frezerskiej 


\subsubsection{Przykładowy proces technologiczny}

Przykładowy proces wykonania rowka w obudowie tubingowej, do której elementów będzie mocowana frezarka, przebiega następująco:

1. ustalić, na jaką średnicę należy wykonać rowek i w związku z wymiarem należy wybrać i zamocować do frezarki odpowiednią głowicę;

2. zamontować frezarkę do prowadnic;

3. zmontować uchwyty $\mathrm{z}$ prowadnicami i frezarka (rys. 8);

4. pozycjonować frezarkę w odpowiednim miejscu;

5. zluzować śruby blokujące obrót prowadnic w uchwytach (dotyczy tylko prowadnic okragłych);

6. przekręcając prowadnice, doprowadzić do równej odległości przeciwległych ostrzy noży od powierzchni tubingu (dotyczy tylko prowadnic okragłych);

7. wkręcić śruby blokujące obrót prowadnic w uchwytach;

8. dosunąć wstępnie głowicę frezarki do obudowy tubingu na odległość 2-5 mm od jego płaszczyzny obracając pokrętła śrub M16×1,5;
9. ustawić na wiertarkowkrętarce odpowiedni bieg (zaleca się pracę na pierwszym biegu), kierunek obrotów oraz wartość momentu obrotowego (zaleca się ustawienie maks. wartości);

10. wsunąć trzpień wiertarkowkrętarki GSR 36 VE-2-Li na wałek przekładni planetarnej, a następnie włączyć obroty wiertarkowkrętarki;

11. pracującą głowicą frezarki wykonać rowek w obudowie tubingu na ustaloną głębokość za pomocą posuwu ręcznego, obracając pokrętła śrub M16×1,5 (w celu poprawnej pracy noży należy wykonywać obroty obu pokręteł równocześnie o tę samą wartość);

12. po wykonaniu obróbki wyłączyć wiertarkowkrętarkę i zdemontować ją z frezarki;

13. po sprawdzeniu, czy wymiary wykonanego rowka są zgodne z wymaganiami, zdemontować frezarkę wraz z prowadnicami i uchwytami z obudowy tubingu, w przypadku konieczności poprawy wymiarów rowka wykonać powtórną obróbkę na takich samych zasadach.

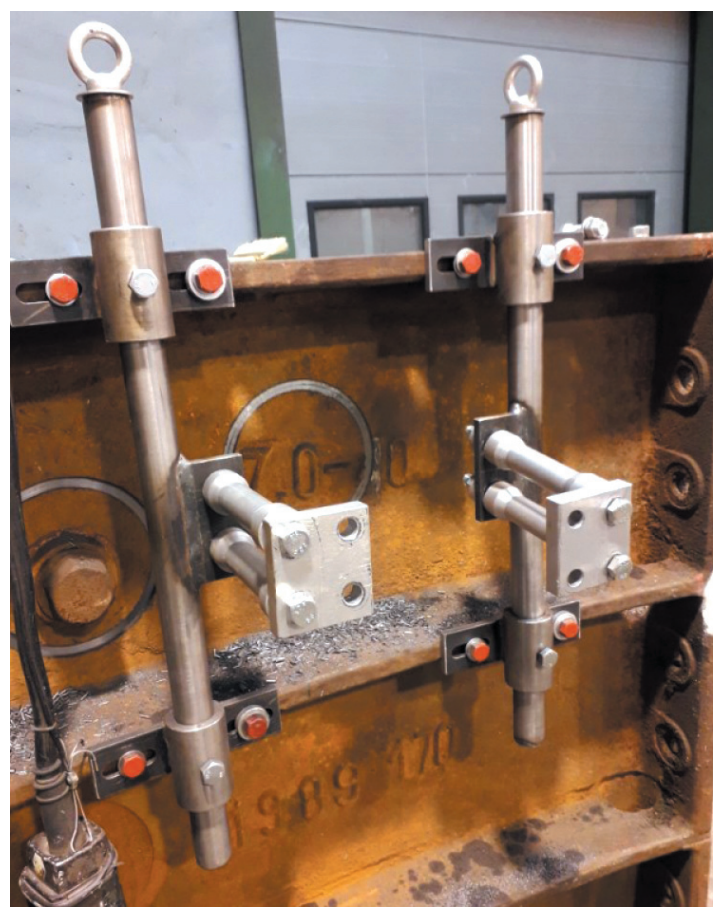

Rys. 8. Uchwyty i prowadnice

Po wykonaniu rowka po jego zewnętrznej stronie zostają wywiercone otwory montażowe o głębności mniejszej niż grubość samego tubingu z wykorzystaniem matrycy do wiercenia (odpowiadającej kształtem rowkowi wykonanemu w tubingu). Następnie w otworach wykonuje się gwinty (do dokładniejszego gwintowania otworów może być wykorzystywana matryca do gwintowania (rys. 11), która również odpowiada kształtem rowkowi wykonanemu w tubingu).
W tak zrobionym rowku osadzana jest wcześniej przygotowana ołowiana uszczelka. Na zdjęciach (rys. 9 i 10) przedstawiono sposób montażu frezarki podczas prób na powierzchni.

Po założeniu uszczelki w rowku do tubingu mocowana jest przestrzenna wkładka w postaci zamkniętego od góry cylindra zaopatrzonego w kołnierz z otworami do mocowania oraz $\mathrm{w}$ wykonany na jego pobocznicy ponad kołnierzem otwór przeznaczony do 
zatłaczania medium uszczelniającego. Dolna część cylindra wchodzi do rowka wykonanego w tubingu i dociska uszczelkę. Cylinder (rys. 12) jest zamocowany do tubingu $\mathrm{z}$ wykorzystaniem śrub, przechodzących przez jego otwory, a wkręcanych w otwory montażowe wykonane wcześniej w tubingu. Po przykręceniu cylindra do tubingu do jego wnętrza przez otwór wykonany na jego pobocznicy wprowadzone zostanie medium uszczelniające, które wypełnia wewnętrzną przestrzeń wkładki oraz uszczelnia pęknięcie. Po zakończeniu wprowadzenia medium uszczelniającego otwór w pobocznicy cylindra zostanie zamknięty korkiem.

W celu zapewnienia prawidłowej pracy frezarki należy zwrócić szczególną uwagę na jej transport, który powinien odbywać się w pozycji poziomej (leżącej) na palecie transportowej za pomocą wózka widłowego. Każdorazowo należy zwrócić uwagę na zabezpieczenie wszystkich elementów frezarki przed uszkodzeniem.
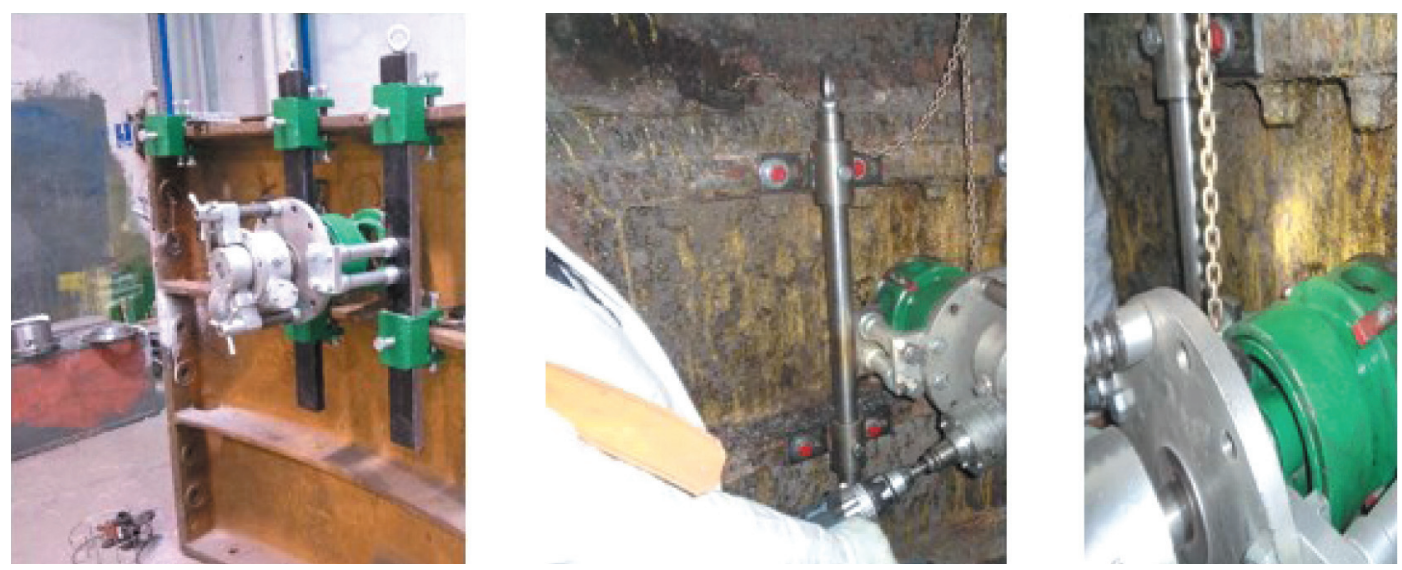

Rys. 9. Frezarka podczas prób wykonywanych na powierzchni

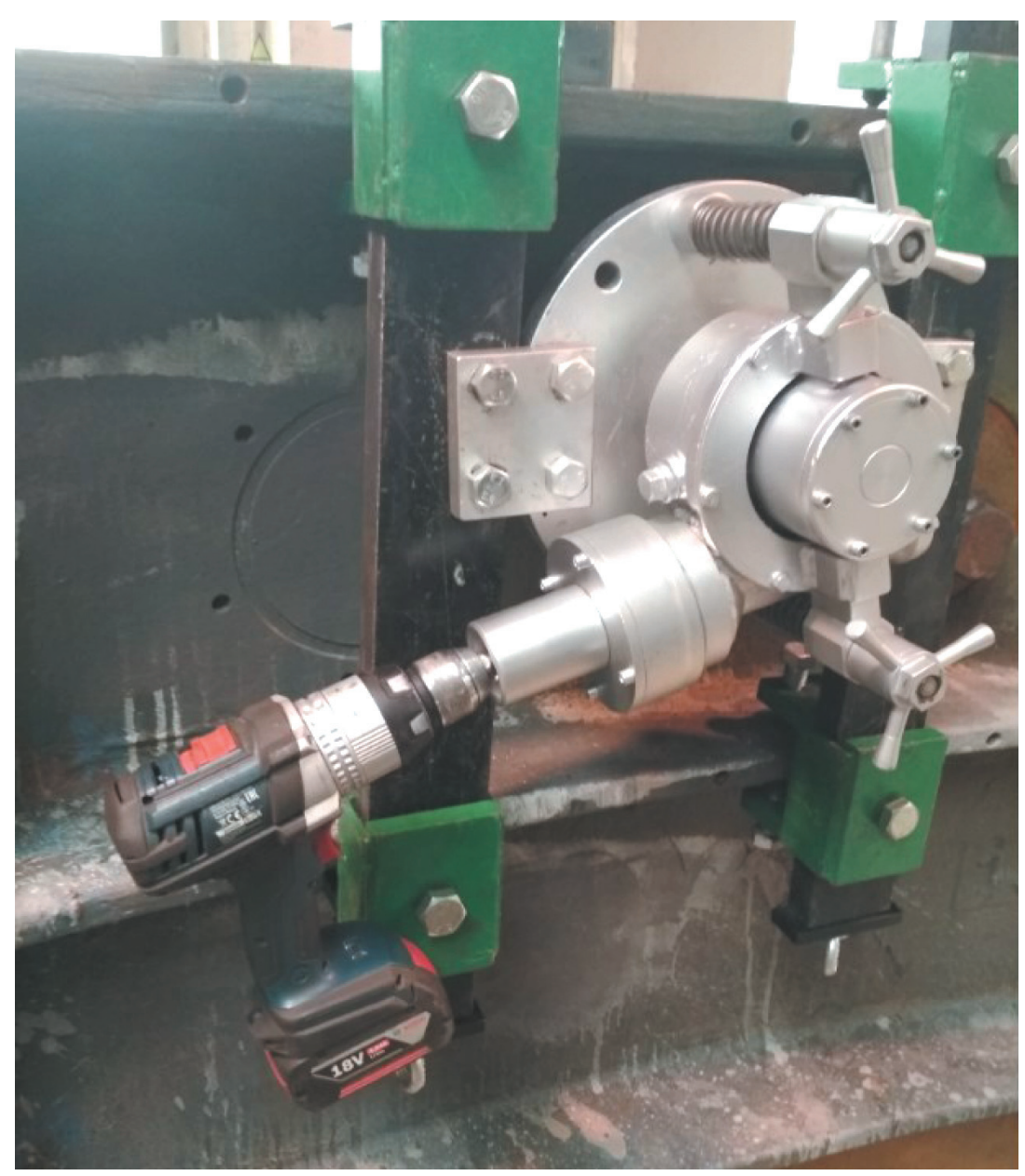

Rys. 10. Frezarka zamocowana do obudowy tubingowej wraz z wiertarkowkrętarka przekazująca napęd 

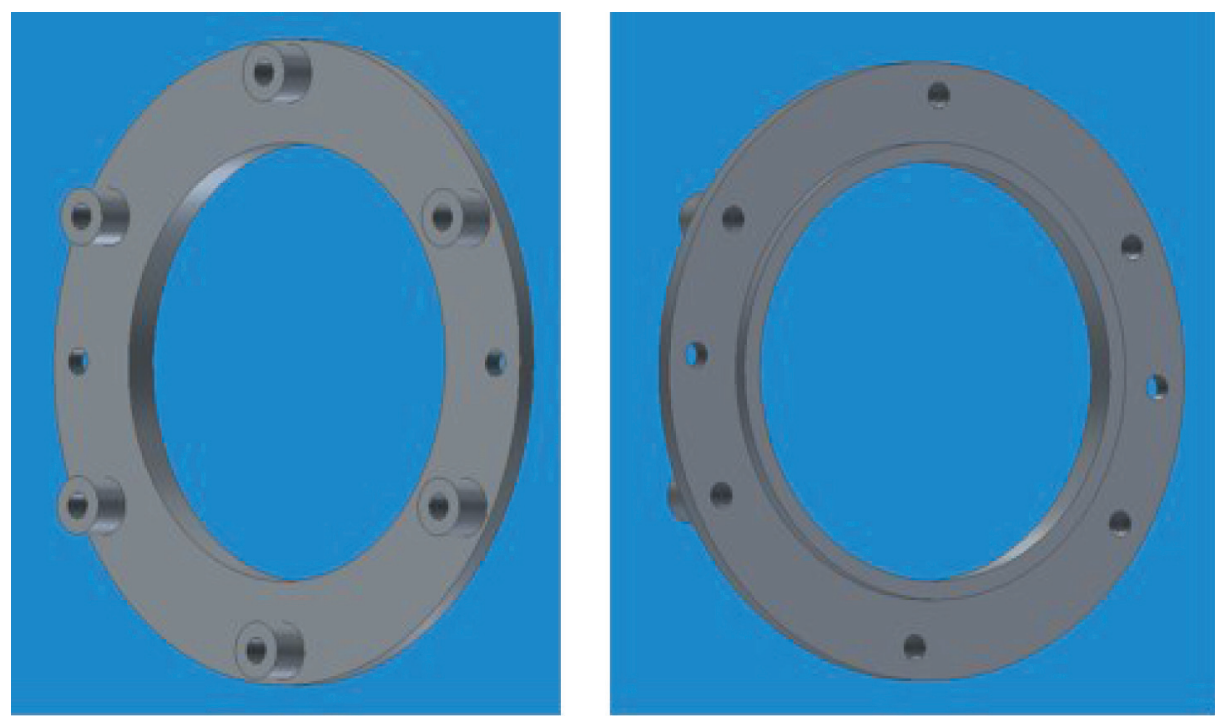

Rys. 11. Matryce do wykonywania otworów

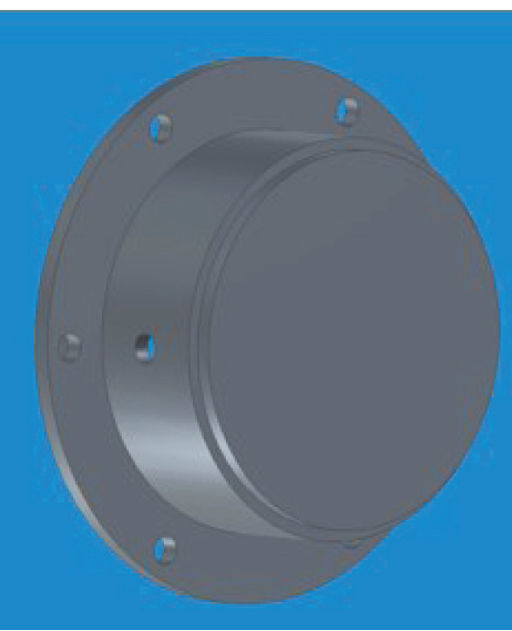

Rys. 12. Cylinder do wypetnienia medium uszczelniajacym
W szybie zalecany jest transport w pozycji poziomej. Jednakże w przypadku ograniczonej powierzchni dopuszcza się transport w pozycji pionowej, zapewniając stabilną pozycję.

Zaleca się transportowanie osobno:

- prowadnic wraz z mocowaniami,

- głowic frezarskich,

- płyty głównej wraz z trzpieniem obrotowym, tuleją gwintowaną, piastą z prowadnicami do prowadzenia noży i mocowaniem układu do płyty głównej oraz z przekładniami planetarną i ślimakową. Do transportu ww. zestawu z płytą główną zaleca się użycie wózka transportowego, jak pokazano na rysunku 13.

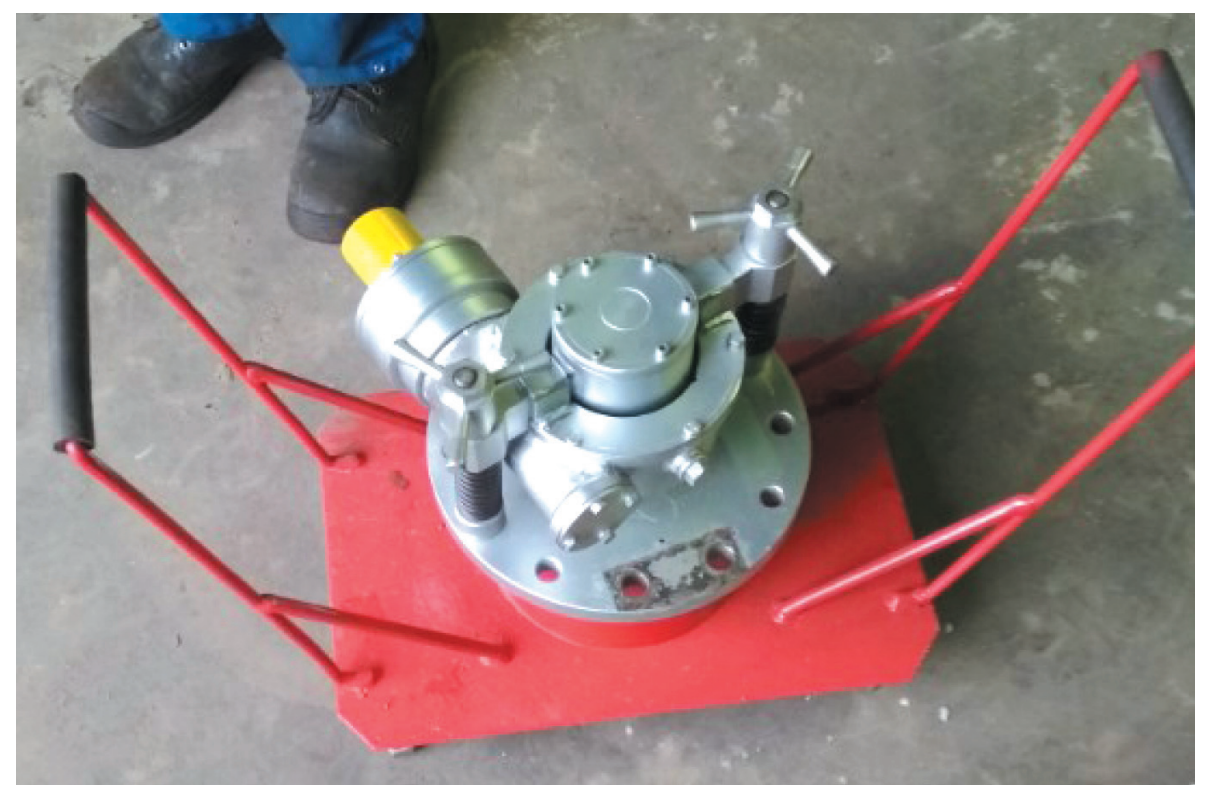

Rys. 13. Wózek do transportu frezarki 


\subsubsection{Certyfikacja}

Frezarka zaprojektowana i wykonana przez Przedsiębiorstwo Budowy Szybów posiada certyfikaty, które pozwalają na stosowanie jej w miejscach zagrożo- nych wybuchem. Konstrukcja urządzenia jest zgodna z dyrektywą Parlamentu Europejskiego i Rady z dnia 17 maja 2006 r. w sprawie maszyn 2006/42/WE.

Tabliczkę znamionową opisywanego urządzenia przedstawiono na rysunku 14.

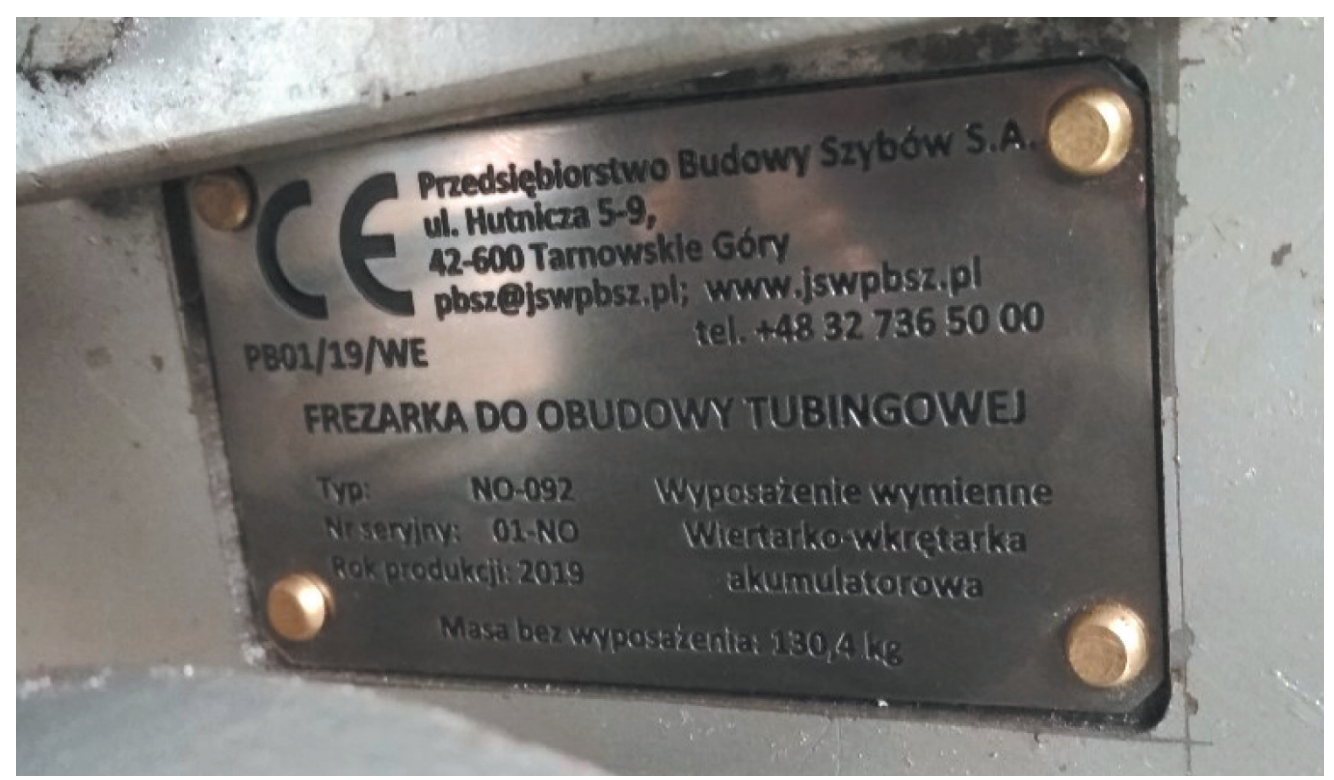

Rys. 14. Tabliczka znamionowa

\section{PODSUMOWANIE}

Sposób uszczelnienia obudowy tubingowej proponowany przez Przedsiębiorstwo Budowy Szybów S.A. jest rozwiązaniem pionierskim, którego zastosowanie zdecydowanie ułatwia proces remontu i rozwiązuje większość problemów technologicznych, które występują podczas tego typu napraw. Dodatkowo urządzenie posiada wszystkie wymagane certyfikaty, które świadczą o jego bezpieczeństwie.

Zastosowanie frezarki do tubingów podczas napraw obudowy tubingowej (związanych $\mathrm{z}$ jej uszczelnieniem) pozwala na znaczne ograniczenie czasu potrzebnego na wykonanie naprawy, co przekłada się na skrócenie czasu, w którym szyb jest wyłączony z użytku.

\section{Literatura}

[1] Kostrz J.: Gtębienie szybów, Biblioteka Szkoły Eksploatacji Podziemnej, Kraków 2014.

[2] Fabich S., Kokot B., Kulicki J., Szlązak M.: Obudowa tubingowa szybów w LGOM: przyczyny uszkodzeń obudowy, stosowana profilaktyka zapobiegania uszkodzeniom oraz metody napraw, „Górnictwo i Geoinżynieria” 2007, 3: 113-125.

[3] Wang L., Cheng Y.P., Ge C.G., Chen J.X., Li W., Zhou H.X., Wang H.F.: Safety technologies for the excavation of coal and gas outburst-prone coal seams in deep shafts, „International Journal of Rock Mechanics and Mining Science” 2013, 57: 24-33.
[4] Chmielewski J., Lekan W., Głuch P.: Nowe rozwiazania obudowy głowic zbiorników retencyjnych $w$ warunkach $L W$,Bogdanka" SA, Budownictwo Górnicze i Tunelowe" 2012, 3: 39-47.

[5] Czaja P., Kamiński P.: Wybrane zagadnienia techniki i technologii głębienia szybów, „Biblioteka Szkoły Eksploatacji Podziemnej”, Kraków 2016.

[6] Kamiński P. Cholewa M.: Technologia i organizacja robót wymiany obudowy szybu Pótnocny II KWK Halemba, Tarnowskie Góry 2018 [prezentacja niepublikowana].

mgr inż. TOMASZ CICHOŃ KRZYSZTOF PYREK mgr inż. KRYSTIAN RATUSZY mgr inż. PIOTR KALINOWSKI Przedsiębiorstwo Budowy Szybów S.A. ul. Hutnicza 5-9, 42-600 Tarnowskie Góry \{tcichon, kpyrek, kratuszny, pkalinowski\}@.jswpbsz.pl

dr inż. PAWEŁ KAMIŃSKI Przedsiębiorstwo Budowy Szybów S.A. ul. Hutnicza 5-9, 42-600 Tarnowskie Góry AGH Akademia Górniczo-Hutnicza im. Stanistawa Staszica ul. Mickiewicza 30, 30-059 Kraków pkaminski@jswpbsz.pl,pkamin@agh.edu.pl 